\title{
NIST Cloud Computing Forensic Science Challenges
}

\author{
Martin Herman \\ Michaela Iorga \\ Ahsen Michael Salim \\ Robert H. Jackson \\ Mark R. Hurst \\ Ross Leo \\ Richard Lee \\ Nancy M. Landreville \\ Anand Kumar Mishra \\ Yien Wang \\ Rodrigo Sardinas
}

This publication is available free of charge from:

https://doi.org/10.6028/NIST.IR.8006

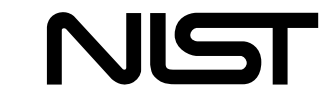

National Institute of Standards and Technology U.S. Department of Commerce 


\section{NIST Cloud Computing Forensic Science Challenges}

Martin Herman

Information Access Division Information Technology Laboratory

Michaela Iorga

Computer Security Division Information Technology Laboratory

Ahsen Michael Salim American Data Technology, Inc. Research Triangle Park, NC

Robert H. Jackson

Mark R. Hurst

SphereCom Enterprises Inc.

Marshall, VA

Ross Leo

University of Houston-Clear Lake

CyberSecurity Institute

Houston, TX
Richard Lee

Citizens Financial Group Johnston, RI

Nancy M. Landreville MELE Associates (Germantown, MD) and Univ. of Maryland, GC (Adelphi, MD)

Anand Kumar Mishra Malaviya National Institute of Technology Jaipur, India Yien Wang Rodrigo Sardinas Auburn University Auburn, $A L$

This publication is available free of charge from: https://doi.org/10.6028/NIST.IR.8006

August 2020

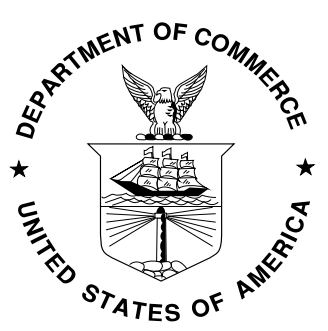

U.S. Department of Commerce Wilbur L. Ross, Jr., Secretary

National Institute of Standards and Technology Walter Copan, NIST Director and Under Secretary of Commerce for Standards and Technology 
NISTIR 8006

\title{
National Institute of Standards and Technology Interagency or Internal Report 8006
}

87 pages (August 2020)

This publication is available free of charge from:

https://doi.org/10.6028/NIST.IR.8006

Certain commercial entities, equipment, or materials may be identified in this document in order to describe an experimental procedure or concept adequately. Such identification is not intended to imply recommendation or endorsement by NIST, nor is it intended to imply that the entities, materials, or equipment are necessarily the best available for the purpose.

There may be references in this publication to other publications currently under development by NIST in accordance with its assigned statutory responsibilities. The information in this publication, including concepts and methodologies, may be used by federal agencies even before the completion of such companion publications. Thus, until each publication is completed, current requirements, guidelines, and procedures, where they exist, remain operative. For planning and transition purposes, federal agencies may wish to closely follow the development of these new publications by NIST.

Organizations are encouraged to review all draft publications during public comment periods and provide feedback to NIST. All NIST Computer Security Division publications, other than the ones noted above, are available at http://csrc.nist.gov/publications.

\section{Comments on this publication may be submitted to:}

\author{
National Institute of Standards and Technology \\ Attn: Computer Security Division, Information Technology Laboratory \\ 100 Bureau Drive (Mail Stop 8930) Gaithersburg, MD 20899-8930 \\ Email: nistir8006@nist.gov
}

All comments are subject to release under the Freedom of Information Act (FOIA). 


\title{
Reports on Computer Systems Technology
}

The Information Technology Laboratory (ITL) at the National Institute of Standards and Technology (NIST) promotes the U.S. economy and public welfare by providing technical leadership for the Nation's measurement and standards infrastructure. ITL develops tests, test methods, reference data, proof of concept implementations, and technical analyses to advance the development and productive use of information technology. ITL's responsibilities include the development of management, administrative, technical, and physical standards and guidelines for the cost-effective security and privacy of other than national security-related information in federal information systems.

\begin{abstract}
This document summarizes research performed by the members of the NIST Cloud Computing Forensic Science Working Group and aggregates, categorizes, and discusses the forensics challenges faced by experts when responding to incidents that have occurred in a cloud-computing ecosystem. The challenges are presented along with the associated literature that references them. The immediate goal of the document is to begin a dialogue on forensic science concerns in cloud computing ecosystems. The long-term goal of this effort is to gain a deeper understanding of those concerns (challenges) and to identify technologies and standards that can mitigate them.
\end{abstract}

\section{Keywords}

cloud computing forensics; digital forensics; forensic science; forensics; forensics challenges. 


\section{Acknowledgments}

This report is dedicated to the memory of our colleague, collaborator, and friend, Ernesto F. Rojas of Forensic \& Security Services Inc., who passed away unexpectedly.

\section{Final Report}

This publication was developed by the NIST Cloud Computing Forensic Science Working Group (NCC FSWG) chaired by Dr. Martin Herman and Dr. Michaela Iorga. NIST and the co-chairs wish to gratefully acknowledge and thank the members whose dedicated efforts contributed significantly to addressing the public comments to the June 2014 Draft report and to updating and enhancing the publication. We also thank Ramaswamy Chandramouli of NIST and Kim-Kwang Raymond Choo of the University of Texas at San Antonio for reviewing the document and providing feedback. 


\section{June 2014 Draft Report}

NOTE: The following section acknowledges the initial collaborators and is reproduced exactly as it appeared in the June 2014 draft report.

This publication was developed by the NIST Cloud Computing Forensic Science Working Group (NCC FSWG), chaired by Dr. Michaela Iorga and Mr. Eric Simmon. The principal editors of this document are Dr. Martin Herman (NIST Senior Adviser) and Dr. Michaela Iorga. NIST, and the principal editors wish to gratefully acknowledge and thank the members whose dedicated efforts contributed significantly to the publication.

The following list (in alphabetical order by last name) includes contributors, ${ }^{1}$ internal reviewers of the document, and other active members who provided feedback and who have agreed to be acknowledged in this document.

CONTRIBUTORS (document and challenges aggregation):

Josiah Dykstra, Ph.D., Department of Defense

Lon Gowen, Ph.D., United States Agency for International Development

Robert Jackson, SphereCom Enterprises Inc.

Otto Scot Reemelin, CBIZ

Ernesto F. Rojas, Forensic \& Security Services Inc.

Keyun Ruan, Ph.D., Espion Group

Mike Salim, American Data Technology, Inc.

Ken E. Stavinoha, Ph.D., Cisco Systems

Laura P. Taylor, Relevant Technologies

Kenneth R. Zatyko, Forensics Technologies \& Discovery Services, Ernst \& Young LLP

\section{INTERNAL REVIEWERS:}

Nancy M. Landreville, University of Maryland University College \& BRCTC

Kristy M. Westphal, Element Payment Services

\section{OTHER ACTIVE MEMBERS:}

Ragib Hasan, Ph.D., Assistant Prof., Dept. of Computer and Information Sciences, Univ. of Alabama at Birmingham

Mark Potter, Danya International

Anthony M. Rutkowski, Yaana Technologies

NOTE: All views expressed in this document by the contributors are their personal opinions and not those of the organizations with which they are affiliated. 


\section{Executive Summary}

The National Institute of Standards and Technology (NIST) has been designated by the Federal Chief Information Officer (CIO) to accelerate the Federal Government's secure adoption of cloud computing by leading efforts to develop standards and guidelines in close consultation and collaboration with standards bodies, the private sector, and other stakeholders.

Consistent with NIST's mission, ${ }^{1}$ the NIST Cloud Computing Program (NCCP) has developed the NIST Cloud Computing Standards Roadmap [1] as one of many mechanisms in support of the U.S. Government's (USG's) secure and effective adoption of cloud computing technology ${ }^{2}$ to reduce costs and improve services. Standards are critical to ensure cost-effective and easy migration, to ensure that mission-critical requirements can be met, and to reduce the risk that sizable investments may become prematurely technologically obsolete. Standards are key elements required to ensure a level playing field in the global marketplace. The importance of setting standards in close relation with private sector involvement is highlighted in a memorandum from the Office of Management and Budget (OMB), M-12-08 [2], dated January 17, 2012.

With the rapid adoption of cloud computing technology, a need has arisen for the application of digital forensic science to this domain. The validity and reliability of forensic science is crucial in this new context and requires new methodologies for identifying, collecting, preserving, and analyzing evidence in multi-tenant cloud $^{3}$ environments that offer rapid provisioning, global elasticity, and broad network accessibility. This is necessary to support the U.S. criminal justice and civil litigation systems as well as to provide capabilities for security incident response and internal enterprise operations.

The NIST Cloud Computing Forensic Science Working Group (NCC FSWG) was established to research forensic science challenges in the cloud environment and to develop plans for standards and technology research to mitigate the challenges that cannot be addressed by current technology and methods. The NCC FSWG has surveyed existing literature and defined a set of challenges related to cloud computing forensics. These challenges, along with associated literature, are presented in this document. The document also provides a preliminary analysis of these challenges by including: (1) the relationship between each challenge to the five essential characteristics of cloud computing as defined in the NIST cloud computing model [3], (2) how the challenges correlate to cloud technology, and (3) nine categories to which the challenges belong. In addition, the analysis considers logging data, data in media, and issues associated with time, location, and sensitive data.

1 This effort is consistent with the NIST role per the National Technology Transfer and Advancement Act (NTTAA) of 1995, which became law in March 1996.

2 NIST Definition of Cloud Computing, NIST Special Publication (SP) 800-145 [3]: Cloud computing is a model for enabling ubiquitous, convenient, on-demand network access to a shared pool of configurable computing resources (e.g., networks, servers, storage, applications, and services) that can be rapidly provisioned and released with minimal management effort or service provider interaction.

3 The NIST definition of cloud computing [3] requires that The Provider's computing resources are pooled to serve multiple Consumers using a multi-tenant model... 


\section{Table of Contents}

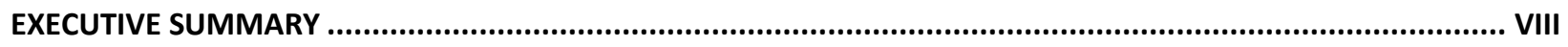

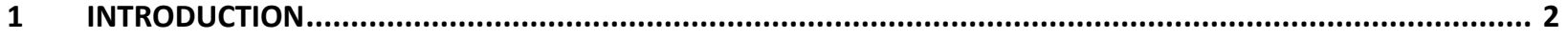

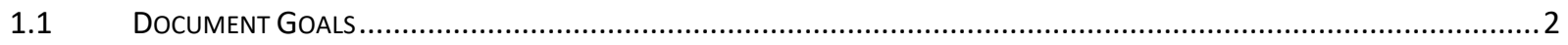

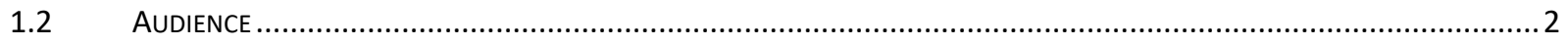

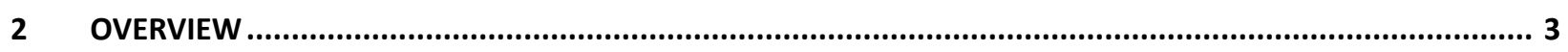

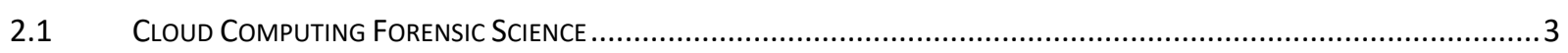

2.2 Defining What Constitutes a Challenge fOR Cloud Computing Forensics ..................................................

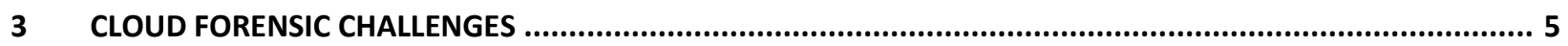

3.1 ColleCtion AND Aggregation of Forensic SCIENCE Challenges ..........................................................

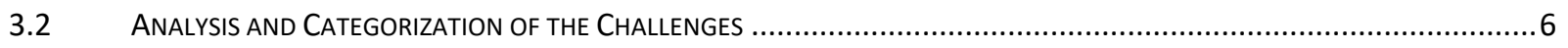

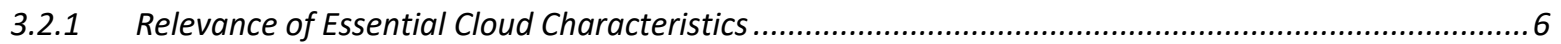

3.2.2 Correlation Between Cloud Technology and Forensic Science Challenges.........................................

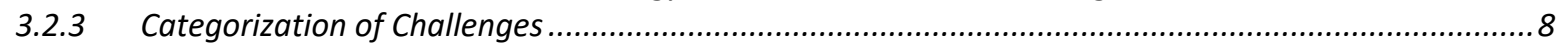

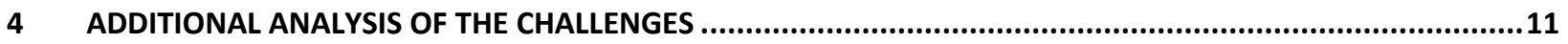

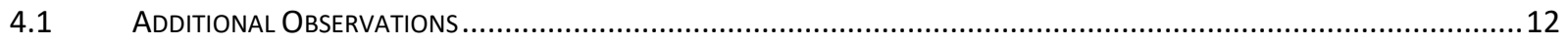

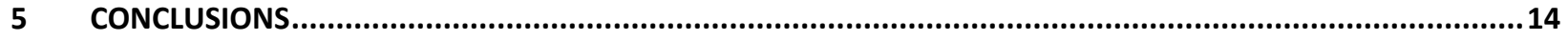

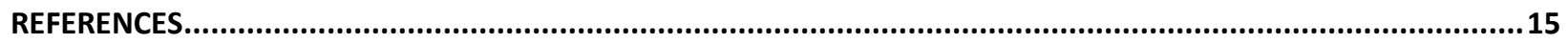

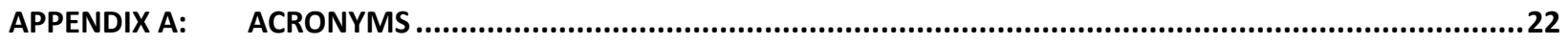

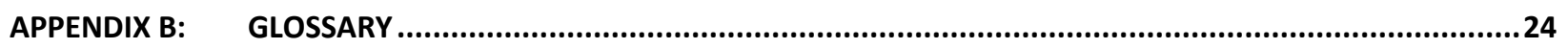

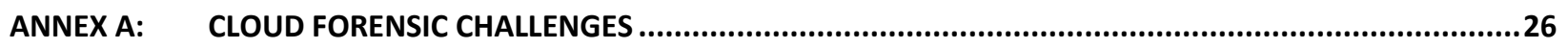

ANNEX B: CSA'S ENTERPRISE ARCHITECTURE (TCI V2.0) ..........................................................................77

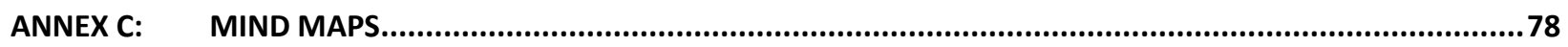

\section{Table of Figures}

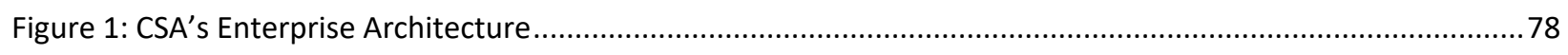

Figure 2: Mind Map - Categories and Subcategories ......................................................................................

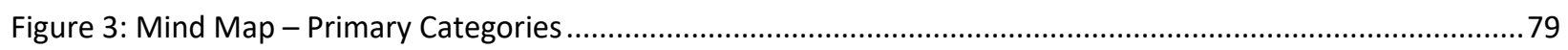

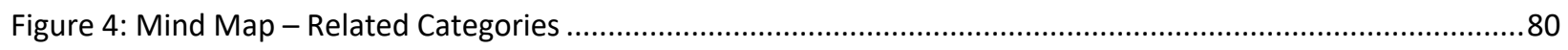




\section{Introduction}

Cloud computing has revolutionized the methods by which digital data is stored, processed, and transmitted. One of the most daunting new challenges is how to perform digital forensics in various types of cloud computing environments. The challenges associated with conducting forensics in different cloud deployment models, which may cross geographic or legal boundaries, have become an issue.

NIST carries out many research activities related to forensic science. The goals of these activities are to improve the accuracy, reliability, and scientific validity of forensic science methods and practices through advances in its measurements and standards infrastructure. As part of these activities, the NIST Cloud Computing Forensic Science Working Group (NCC FSWG) is identifying emerging standards and technologies that would help solve challenges, that is, the most pressing problems fundamental to carrying out forensics in a cloud computing environment to lawfully obtain (e.g., via warrant or subpoena) all relevant artifacts, as well as to provide capabilities for security incident response and internal enterprise operations.

The cloud exacerbates many technological, organizational, and legal challenges already faced by digital forensic examiners. Several of these challenges - such as those associated with data replication, location transparency, and multi-tenancy - are somewhat unique to cloud computing forensics [4], [72]. The NCC FSWG has collected and aggregated a list of cloud forensic challenges (see Annex A) that are introduced and discussed in this document. Future work will involve identifying gaps in technology and standards related to the challenges that need to be addressed and developing possible technological and standards approaches to mitigate these challenges.

\subsection{Document Goals}

This document is intended to serve as a basis for a dialogue on forensic science concerns in cloud Ecosystems ${ }^{4}$ and as a starting point for understanding those concerns (challenges) with the intent of allowing the cloud computing community to identify the technologies and standards that can mitigate these challenges.

\subsection{Audience}

The primary audience for this document includes digital forensic examiners, developers and researchers, cloud security professionals, law enforcement officers, and cloud Auditors. However, given the breadth and depth of this topic, many other stakeholders - such as cloud policy makers, executives, and the general user population of cloud Consumers - may also be interested in certain aspects of this document.

4 The term Ecosystems is capitalized here for consistency with the capitalization of cloud-related terms in other NIST publications. Other terms to be capitalized in this report include cloud Actor, Provider, Consumer, Auditor, Broker and Carrier. 


\section{Overview}

This section discusses the characteristics of cloud computing forensic science, elaborates on why cloud computing challenges traditional digital forensics methods, and describes what constitutes a challenge for cloud forensics.

\subsection{Cloud Computing Forensic Science}

Many experts consider forensic science to be the application of a broad spectrum of sciences and technologies to the investigation and establishment of facts of interest in relation to criminal law, civil law, or regulatory issues. The rapid advance of cloud services requires the development of better forensic tools to keep pace. However, the resulting techniques may also be used for purposes other than legal and regulatory issues to reconstruct an event that has occurred.

Cloud computing forensic science is the application of scientific principles, technological practices, and derived and proven methods to reconstruct past cloud computing events through the identification, acquisition, preservation, examination, interpretation, and reporting of potential digital evidence.

NIST defines cloud computing as a model for enabling ubiquitous, convenient, on-demand network access to a shared pool of configurable computing resources (e.g., networks, servers, storage, applications, and services) that can be rapidly provisioned and released with minimal management effort or service Provider interaction. This cloud model is composed of five essential characteristics, three service models, and four deployment models [3]. Cloud forensics is a process applied to an implementation of this cloud model.

A number of researchers have defined cloud forensics as the application of digital forensic science in cloud environments [4], [72], [73]. Technically, it consists of a hybrid forensic approach (e.g., remote, virtual, network, live, large-scale, thin-client, thick-client, including end-point devices used to access cloud services) to the discovery of digital evidence. Organizationally, it involves interactions among cloud Actors (i.e., Provider, Consumer, Broker, Carrier, Auditor) for the purpose of facilitating both internal and external investigations. Legally, it often implies multijurisdictional and multi-tenant situations.

Various process models have been developed for digital forensics, including the following eight distinctive steps and attributes [5]:

1. Search authority. Legal authority is required to conduct a search and/or seizure of data.

2. Chain of custody. In legal contexts, chronological documentation of access and handling of evidentiary items is required to avoid allegations of evidence tampering or misconduct.

3. Imaging/hashing function. When items containing potential digital evidence are found, each should be carefully duplicated and then hashed to validate the integrity of the copy.

4. Validated tools. When possible, tools used for forensics should be validated to ensure reliability and correctness.

5. Analysis. Forensic analysis is the execution of investigative and analytical techniques to examine, analyze, and interpret the evidentiary artifacts retrieved. 
6. Repeatability and reproducibility (quality assurance). The procedures and conclusions of forensic analysis should be repeatable and reproducible by the same or other forensic analysts [6].

7. Reporting. The forensic analyst must document his or her analytical procedure and conclusions for use by others.

8. Presentation. In most cases, the forensic analyst will present his or her findings and conclusions to a court or other audience.

In order to carry out digital forensic investigations in the cloud, these steps need to be applied or adapted to the cloud context. Many of them pose significant challenges. This document is focused on the forensic analysis of artifacts retrieved from a cloud environment. A related discipline, which is not addressed here, focuses on carrying out the forensic process using a cloud environment. This involves using the cloud to perform examination and analysis of digital evidence [6]

\subsection{Defining What Constitutes a Challenge for Cloud Computing Forensics}

The numerous challenges for the various stakeholders who share an interest in forensic analysis of cloud computing environments can be broadly categorized into technical, legal, and organizational ${ }^{5}$ challenges. These challenges occur when identification and acquisition tasks become impeded or when examination and interpretation by a digital forensic examiner is prevented.

Compared to the challenges of traditional digital forensics, those of cloud forensics are considered to either be unique to the cloud environment or exacerbated by the cloud environment [4]. While the goals of first responders and forensic examiners may be the same in the cloud context as in traditional, large-scale computer and network forensics, distinctive features of cloud computingsuch as segregation of duties among cloud Actors, inability to acquire system and network logs, multi-tenancy, and rapid elasticity - introduce unique scenarios to digital investigations. On the other hand, challenges associated with, for example, virtualization, large-scale data processing, and the proliferation of mobile devices and other endpoints are exacerbated in the cloud.

Cloud forensic challenges cannot be solved by technological, legal, or organizational principles alone. Many of the challenges need solutions from all three areas, and scholars and practitioners have been discussing these challenges. This report focuses more on the technical challenges (which need to be understood in order to develop technology) and standards-based mitigation approaches.

5 Organizational challenges involve cloud Actors working together to obtain digital evidence. Cloud Actors include Consumers, Providers, Brokers, Auditors, and Carriers [4]. 


\section{Cloud Forensic Challenges}

This section discusses how the NCC FSWG collected and aggregated the challenges and provides an analysis and categorization of those challenges.

\subsection{Collection and Aggregation of Forensic Science Challenges}

The first step in identifying the challenges that cloud forensic examiners face was to study the existing literature and gather available data on this topic. The data was then aggregated as a collective group effort by the active participants of the $\mathrm{NCC} \mathrm{FSWG}^{6}$ in a meaningful way that allowed for further analysis. The methodology for gathering the data was as follows:

- Perform a literature search. Most of these sources are listed in the References Section (Section 8).

- Obtain input from a variety of stakeholders in the group.

- Have various group discussions among the participants through scheduled conference calls as well as emails.

The data gathered was inserted into two tables (shown in Annex A) that currently list 62 challenges, including challenge descriptions, results of overcoming the challenges, relevance of cloud computing essential characteristics [3], correlations between challenges and functionalcapabilities, categories of the challenges, and relevant references in the literature.

The major objectives of these tables are to:

- Identify the major challenges in conducting digital forensics procedures where the evidence resides in a cloud computing environment. While there are challenges in conducting any digital forensics procedure, the essential characteristics of cloud computing systems enumerated in Section 3.2 provide many challenges that are not encountered or are encountered to a lesser degree in more traditional computing models.

- Create an ongoing dialogue among stakeholders to define potential technology- and standards-based approaches to the mitigation of forensic challenges faced in the cloud computing environment. The challenges identified in the Cloud Forensic Challenges tables (Annex A) are certainly not comprehensive and will continue to evolve. The long-term objectives are to identify technology and standards gaps related to the challenges that need to be addressed and to develop possible technological and standards approaches to mitigate those challenges.

Taken as a whole, the items identified by the Cloud Forensic Challenges tables represent many of the major challenges that arise while performing digital forensics in the cloud environment based on the collective experience of the NCC FSWG. The NCC FSWG hopes that by initiating this dialogue, the experience of other professionals can be drawn upon to further refine and update this information.

\footnotetext{
${ }^{6}$ These active participants represent numerous key cloud Ecosystem stakeholders, including government, industry, and academia, both domestically and internationally.
} 


\subsection{Analysis and Categorization of the Challenges}

Once the forensic science challenges were collected and aggregated, a multi-dimensional analysis and categorization of these challenges were performed to identify each one's cloudbased root cause and to organize them in categories that are agnostic to cloud Providers or cloud service models.

\subsubsection{Relevance of Essential Cloud Characteristics}

The NCC FSWG intended to keep the challenges generic and, therefore, disregarded the myriad architectural differences among the many cloud computing family of offerings when analyzing the aggregated challenges.

Additionally, the team targeted only the digital forensic challenges unique to or exacerbated by the cloud environment. To assist in filtering out the challenges that do not have a cloud-based root cause, the team analyzed each challenge through the lens of the five essential characteristics of the cloud computing model as defined in The NIST Definition of Cloud Computing [3]. These characteristics are used to identify whether a challenge has a cloud-based root cause. Table 2 of Annex A captures this analysis in the third column, which identifies the characteristics most relevant to each challenge. The essential characteristics of the cloud computing model are reproduced below:

- On-demand self-service: A Consumer can automatically and unilaterally provision computing capabilities, such as server time and network storage, as needed without requiring human interaction with each cloud service Provider.

- Broad network access: Capabilities are available over the network and accessed through standard mechanisms that promote use by heterogeneous thin or thick client platforms (e.g., mobile phones, tablets, laptops, and workstations).

- Resource pooling: The Provider's computing resources are pooled to serve multiple Consumers using a multi-tenant model with different physical and virtual resources dynamically assigned and reassigned according to consumer demand. There is a sense of location independence in that the Consumer generally has no control over or knowledge of the exact location of the provided resources but may be able to specify location at a higher level of abstraction (e.g., country, state, or data center). Examples of resources include storage, processing, memory, and network bandwidth.

- Rapid elasticity: Capabilities can be elastically provisioned and released, in some cases automatically, to rapidly scale outward and inward commensurate with demand. To the Consumer, the capabilities available for provisioning often appear to be unlimited and can be appropriated in any quantity at any time.

- Measured service: Cloud systems automatically control and optimize resource use by leveraging a metering capability at some level of abstraction appropriate to the type of service (e.g., storage, processing, bandwidth, and active user accounts). Resource usage can be monitored, controlled, and reported, providing transparency for both the Provider and Consumer of the utilized service. 


\subsubsection{Correlation Between Cloud Technology and Forensic Science Challenges}

To better understand the correlation between the cloud forensic science challenges and their cloud-based root cause, the NCC FSWG analyzed each challenge's relationship to the cloud functional capabilities (cloud processes or solutions) identified in the Cloud Security Alliance's (CSA's) Enterprise Architecture (EA) [9] and leveraged by the NIST Cloud Security Reference Architecture (CSRA) [10].

The CSA's EA, reproduced in Annex C, Fig. 1, covers the following domains:

a. Business Operations and Support (BOSS) - has capabilities associated with cloud IT services to support an organization's business needs.

b. Information Technology Operation \& Support (ITOS) - has capabilities associated with managing the cloud IT services of an organization.

c. Security and Risk Management (S \& RM) - has capabilities associated with safeguarding cloud IT assets and detecting, assessing, and monitoring cloud IT risks.

The CSA's EA also identifies the corresponding data grouping into the following service layers:

d. Presentation Services - has capabilities associated with the end user interacting with a cloud IT solution.

e. Application Services - has capabilities associated with the development and use of cloud applications provided by an organization.

f. Information Services - has capabilities associated with storage and the use of cloud information and data.

g. Infrastructure Services - has capabilities associated with core functions that support the cloud IT infrastructure, such as facilities, hardware, networks, and virtual environments.

Altogether, there are 347 functional capabilities listed within these categories.

The correlations between the forensic challenges and these functional capabilities were examined by determining the relationship between a particular forensic challenge and a particular functional capability (all possible pairs of challenges and capabilities were considered) and by labeling the challenge (as describe below) based on the functional capabilities affected.

The relationship was determined by:

1. Clarifying what it means for a challenge to be overcome (see Annex A, Table 1, column 5 that identifies what would be the result if the challenge were, in fact, overcome?) and

2. Answering the question, If the challenge were overcome, would that make it easier to conduct a cloud forensic investigation on the considered functional capability? ${ }^{7}$

Analysis of the correlation between the forensic science challenges and the functional capabilities constitutes the foundation for labeling each challenge based on the functional capabilities affected by the challenge. Each challenge is labeled along a generic-to-specific axis (see Annex A, Table 2, column 4). A challenge is labeled generic if it applies to most of the

\footnotetext{
${ }^{7}$ The results of this analysis will be presented in a future NIST publication.
} 
capabilities. A challenge is labeled specific if it applies to a limited set of capabilities. A challenge is labeled quasi if it falls somewhere between generic and specific.

\subsubsection{Categorization of Challenges}

A review of the Annex A challenges reveals that a majority of the issues are technical in nature with a major secondary group that is framed by legal and organizational issues. The technical issues revolve around the differences between the operating framework of cloud computing and traditional data center computing. The legal and organizational issues primarily reflect the crossing of national borders and legal jurisdictions by the manner in which cloud Providers store cloud Consumer's information for operational redundancy, cost, and reliability.

To facilitate a more detailed understanding and analysis of the identified challenges, they have been organized into the mind map shown in Annex C. The mind map provides a graphic depiction of the relationship between challenges and was used to structure and classify them into categories. The highest level of the mind map (presented in blue text) represents the complete set of challenges that are identified in Annex A.

To assist in a meaningful analysis, the challenges are categorized into the following nine major groups (presented in red text in the mind map). The categories and associated descriptions below provide a summary of the contents of Annex A. Some of the challenges lie in more than one category because, as will be described, a challenge may be part of a primary category and also part of a different related category. Refer to Annex A, Table 2 for the details.

- Architecture (e.g., diversity, complexity, provenance, multi-tenancy, data segregation). Architecture challenges in cloud forensics include:

- Dealing with variability in cloud architectures between Providers

- Tenant data compartmentalization and isolation during resource provisioning

o Proliferation of systems, locations, and endpoints that can store data

- Accurate and secure provenance for maintaining and preserving chain of custody

- Data collection (e.g., data integrity, data recovery, data location, imaging). Data collection challenges in cloud forensics include:

- Locating forensic artifacts in large, distributed, and dynamic systems

$\circ$ Locating and collecting volatile data

- Data collection from virtual machines

- Data integrity in a multi-tenant environment where data is shared among multiple computers in multiple locations and accessible by multiple parties

O Inability to image all of the forensic artifacts in the cloud

- Accessing the data of one tenant without breaching the confidentiality of other tenants

O Recovery of deleted data in a shared and distributed virtual environment

- Analysis (e.g., correlation, reconstruction, time synchronization, logs, metadata, timelines). Analysis challenges in cloud forensics include:

○ Correlation of forensic artifacts across and within cloud Providers

o Reconstruction of events from virtual images or storage

- Integrity of metadata

○ Timeline analysis of $\log$ data, including synchronization of timestamps 
- Anti-forensics (e.g., obfuscation, data hiding, malware). Anti-forensics are a set of techniques used specifically to prevent or mislead forensic analysis. Anti-forensic challenges in cloud forensics include:

○ The use of obfuscation, malware, data hiding, or other techniques to compromise the integrity of evidence

- Malware may circumvent virtual machine isolation methods

- Incident first responders (e.g., trustworthiness of cloud Providers, response time, reconstruction). Incident first responder challenges in cloud forensics include:

o Confidence, competence, and trustworthiness of the cloud Providers to act as first responders and perform data collection

o Difficulty in performing initial triage

o Processing a large volume of collected forensic artifacts

- Role management (e.g., data owners, identity management, users, access control). Role management challenges in cloud forensics include:

○ Uniquely identifying the owner of an account

- Decoupling between cloud user credentials and physical users

- Ease of anonymity and creating fictitious identities online

- Determining exact ownership of data

o Authentication and access control

- Legal (e.g., jurisdictions, laws, service level agreements, contracts, subpoenas, international cooperation, privacy, ethics). Legal challenges in cloud forensics include:

O Identifying and addressing issues of jurisdictions for legal access to data

$\circ$ Lack of effective channels for international communication and cooperation during an investigation

- Data acquisition that relies on the cooperation of cloud Providers, as well as their competence and trustworthiness

O Missing terms in contracts and service level agreements

○ Issuing subpoenas without knowledge of the physical location of data

- Standards (e.g., standard operating procedures, interoperability, testing, validation). Standards challenges in cloud forensics include:

○ Lack of even minimum/basic SOPs, practices, and tools

○ Lack of interoperability among cloud Providers

- Lack of test and validation procedures

- Training (e.g., forensic investigators, cloud Providers, qualification, certification). Training challenges in cloud forensics include:

- Misuse of digital forensic training materials that are not applicable to cloud forensics

o Lack of cloud forensic training and expertise for both investigators and instructors

o Limited knowledge by record-keeping personnel in cloud Providers about evidence

Once the challenges were grouped into their primary categories, it was determined that several challenges could logically be grouped into subcategories (presented in green text on the mind 
map). For example, Data Integrity and Data Recovery were determined to be two important subcategories of the Data Collection category because multiple data collection challenges could logically be grouped into these subcategories. Annex C.1 is the mind map that represents these categories and subcategories. Once all of the categories and subcategories were identified, each of the challenges in Annex A was analyzed in relationship to the other challenges and mapped into the appropriate category (and subcategory, if appropriate). These challenges (presented in black text on the mind map) are the end nodes for each path through the mind map.

During this preliminary analysis, it was also discovered that while every challenge could be logically grouped into a primary category, many of the challenges overlapped into other categories. Within Table 2 in Annex A, the latter challenges are identified as belonging to one or more related categories. The primary and related category information is represented in the mind maps shown in Annex C. Different node background colors were selected for primary and related categories. A challenge's primary category is depicted by a green node background (Annex C.2 shows the primary categories), while a challenge's related category is depicted by an orange background (Annex C.3 shows the related categories). 


\section{Additional Analysis of the Challenges}

The study examined challenges related to cloud computing forensics, and this section provides additional insight into the nature of these challenges.

In traditional computer forensics, the centralized nature of IT systems allows investigators to have full control over the forensic artifacts (e.g., router logs, process logs, hard disks). However, in a cloud Ecosystem, the distributed nature of IT systems dictates that control over the functional layers varies among cloud Actors depending on the cloud service model. Therefore, investigators have a lower level of visibility and control over the forensic artifacts. For example, cloud Consumers have the highest level of control over the functional stack in an Infrastructure as a Service (IaaS) model and the least level of control in a Software as a Service (SaaS) model. Because of this difference in control, evidence collection varies according to the service model [11].

Important sources of forensic analysis are logs, many of which may be available in cloud computing environments but may be hard to access or aggregate due to the segregation of duties among Actors and the lack of transparency of log data for the Consumer. Three examples of such logs are audit, security, and application logs. Audit logs are the records of interactions between services and the underlying operating system. Security logs trace users to actions by identifying the particular user who took an action on a particular date at a particular time. Application logs record activity generated by the applications along with errors and other operational faults of the applications.

When there is a potential need for forensic artifacts at the hypervisor/virtual machine monitor (VMM) layers in cloud computing, additional complexities arise from the architecture of the cloud Ecosystem. Just as there can be significant differences in how Windows, Linux, and other operating systems create and handle events, there are different architectures and configurations for hypervisors/VMMs from different manufacturers, and each has its own event definition and logging (or lack thereof). Another level of variability and complexity is added by the fact that the quantity and quality of log data for cloud products are often configurable by the cloud Providers and/or Consumers [6]. Cloud computing can present a challenge to the acquisition of artifacts if, for example, the creation and migration of a virtual path or virtual asset needs to be ascertained across several virtual platforms or cloud Providers.

To perform forensic analysis using logs with integrity on which all stakeholders can rely, the logs must be trusted [12]. Differences in log formats, decentralization of logs among different layers, lack of accessibility to logs, the multi-tenancy nature of clouds, and the need to preserve the chain of custody make log analysis challenging in clouds. Additionally, the use of logs in hypervisors is not well-understood and presents a significant challenge to cloud forensics.

The identification, collection, and preservation of media can be particularly challenging in a cloud computing environment because of several possible factors, including:

1) The identification of the cloud Provider and its partners, which is needed to better understand the environment and thus address the factors below

2) The ability to conclusively identify the proper accounts held within the cloud by a Consumer, especially if different identities are used

3) The ability of the forensic examiner to gain access to the desired media 
4) The ability to obtain assistance from the cloud infrastructure/application Provider service staff

5) An understanding of the topology, proprietary policies, and storage systems within the cloud.

6) The examiner's ability to complete a forensically sound image of the media once access is obtained

7) The sheer volume of the media

8) The ability to respond in a timely fashion to more than one physical location, if necessary

9) E-discovery, log file collection, and privacy rights, given a multi-tenancy system (e.g., how does one collect the set of log files applicable for this matter versus extraneous information with possible privacy rights protections?)

10) Validation of the forensic image

11) The ability to perform analysis on encrypted data and the forensic investigator's ability to obtain keys for decryption

12) The storage system no longer being local

13) Often no way to link given evidence to a particular individual other than by relying on the cloud Provider's word, although there may be evidence in the client endpoint that can link the individual to evidence in the cloud [6]

Standards and technologies need to be developed to address these challenges. For example, forensic protocols need to be developed that can be adopted by the major cloud Providers. These protocols must adequately address the needs of first responders, law enforcement, and court systems while assuring cloud Providers that there will be minimal or no disruption to their service(s). On the technology front, an example of a current need is the ability to lawfully perform remote digital forensics collections that will lower the cost of travel. In essence, this will involve electronically moving forensic images and metadata from the cloud Provider to a forensics lab. Potential approaches include a documented process for the remote, programmatic collection of evidential data like the one proposed in [6] or even performing the forensics in a scientifically sound manner in the cloud itself.

\subsection{Additional Observations}

During preliminary analysis, some common topics were identified in these challenges, each of which overlaps several of the categories enumerated in the mind map. These topics appear to be orthogonal to those categories and are included here to provide additional insight into the challenges.

- Time - Time is frequently a critical issue as it relates to time synchronization and the possible disappearance of evidence that is not quickly found, as Zimmerman and Glavach [13] point out. Once the information source is identified, do all involved entities have the time synchronized using a consistent time source such as Network Time Protocol (NTP)? If a forensic expert has a difficult time convincing your legal counsel that the time stamps from client-side log files match time stamps on provider-side log files, the forensics will be difficult to defend. In addition to using NTP to ensure that all server time is synced, the issue of time 
zones used in timestamps must be addressed in cloud forensics. Not all systems use Coordinated Universal Time (UTC) timestamps; when recorded in local time, the time zone offset must be collected from the server. Additionally, if evidence is not found quickly enough, it may be overwritten or lost in some other manner. Some example challenges in Annex A related to time include FC-05 (Timestamp synchronization), FC-14 (Real-time investigation intelligence processes not possible), FC-30 (Data available for a limited time), and FC-53 (International cloud services).

- Location - Locating digital media can be a time-consuming process in cloud environment cases. Both backup and redundant storage are important, and an understanding of the topology will aid in identifying physical locations of media storage. Locating the evidence can be a big hurdle. As pointed out by Zimmerman and Glavach [13], before network or computer forensics can begin, the network or computer must be 'found.' There may only be traces of a virtual machine (VM) because the VM may reside on dispersed, internationally-located physical drives. When forensic data is collected on a physical resource, the justification for collecting that data on that particular resource must be shown by showing the validity of the logical to physical mapping. This is critical since all components - computing, network and storage are virtualized in the cloud. Some example challenges in Annex A related to location include FC17 (Multiple venues and geo-locations), FC-25 (Decreased access and data control), FC-27 (Locating evidence), FC-37 (Additional evidence collection), FC-48 (Physical data location), and FC-60 (Decoupling user credentials \& physical location).

- Sensitive data - Sensitive data theft cases (insider, outsider, and both working together) are an important issue. According to CIO.com [14], the U.S. Commission on Intellectual Property estimates over $\$ 300$ billion in annual losses to U.S. companies due to theft. The pervasive personal use of cloud computing environments by employees could heighten the risk of insider theft given the low-cost storage arrays available and low-cost, high-speed bandwidth to move data. The intrusion threat has grown for all systems connected to the internet. Some example challenges in Annex A related to sensitive data include FC-39 (Selective data acquisition), FC56 (Confidentiality and Personally Identifiable Information [PII]), FC-61 (Authentication and access control), and FC-07 (Use of metadata). 


\section{Conclusions}

This document highlights many of the forensic challenges in the cloud computing environment for digital forensic examiners, cloud Providers, law enforcement, and others. The information in this document was developed as a result of examining recent research papers and involved the international community. It provides a definition of cloud computing forensics to scope this area and describes the relationship of each challenge to the five essential characteristics of cloud computing. The document also discusses how the challenges correlate to cloud technology by considering their relationship to the Cloud Security Alliance's Enterprise Architecture. The categories of challenges include architecture, data collection, analysis, anti-forensics, incident first responders, role management, legal issues, standards, and training. Finally, the results of overcoming each challenge are provided.

As pointed out in [15], more research is required in the cyber domain, especially in cloud computing, to identify and categorize the unique aspects of where and how digital evidence can be found. End points such as mobile devices add complexity to this domain. Trace evidence can be found on servers, switches, routers, cell phones, etc. Digital evidence can be found at the expansive scenes of the crime which includes numerous computers as well as peripheral devices. To aid in this quest, digital forensics standards and frameworks for digital forensics technologies are required now more than ever in our networked environment. This was also echoed in a more recent literature survey [74], which also identified a number of cloud forensic research and operational challenges, such as the need for a forensic-by-design framework that allows integration of forensic tools into the development of cloud physical system to mitigate risks and enable forensic capabilities.

The NCC FSWG will continue its efforts and initiate more dialogue among stakeholders. The next steps include: (1) further analyzing the cloud forensic challenges, (2) prioritizing the challenges, (3) developing a Cloud Forensics Reference Architecture, (4) choosing the highest priority challenges and determining the corresponding gaps in technology and standards that need to be addressed, and (5) developing a roadmap to address these gaps. 


\section{References}

[1] Hogan M, Liu F, Sokol A, Tong J (2011) NIST Cloud Computing Standards Roadmap. (National Institute of Standards and Technology, Gaithersburg, MD), NIST Special Publication (SP) 500-291.

https://tsapps.nist.gov/publication/get_pdf.cfm?pub_id=909024

[2] Executive Office of the President (2012), Principles for Federal Engagement in Standards Activities to Address National Priorities, January 17, 2012 https://www.whitehouse.gov/sites/whitehouse.gov/files/omb/memoranda/2012/m-12$\underline{08 \text { 1.pdf }}$

[3] Mell P, Grance T (2011) The NIST Definition of Cloud Computing. (National Institute of Standards and Technology, Gaithersburg, MD), NIST Special Publication (SP) 800145. https://doi.org/10.6028/NIST.SP.800-145

[4] Ruan K, Carthy J, Kechadi T, Crosbie M (2011) Cloud Forensics. 7th IFIP Advances in Digital Forensics VII, G. Peterson and S. Shenoi (eds), vol. 361, pp. 35-46.

[5] Zatyko K (2007) Commentary: Defining Digital Forensics. Forensic Magazine, January 2, 2007.

[6] Martini B, Choo KR, (2014) Remote Programmatic vCloud Forensics: A Six-Step Collection Process and a Proof of Concept. Proceedings of the 13th IEEE International Conference on Trust, Security and Privacy in Computing and Communications (TrustCom), 24-26 September 2014.

[7] Buchanan W, Graves J, Bose N, Macfarlane R, Davison B, Ludwiniak R, (2011) Performance and student perception evaluation of cloud-based virtualized security and digital forensics labs. In HEA ICS Conference.

[8] Liu F, Tong J, Mao J, Bohn RB, Messina JV, Badger ML, Leaf DM (2011) NIST Cloud Computing Reference Architecture (National Institute of Standards and Technology, Gaithersburg, MD), NIST Special Publication (SP) 500-292. https://doi.org/10.6028/NIST.SP.500-292

[9] Cloud Security Alliance, Trusted Cloud Initiative, Enterprise Reference Architecture, https://downloads.cloudsecurityalliance.org/initiatives/tci/TCI_Reference_Architectur e v2.0.pdf

[10] NIST SP 500-299: Cloud Security Reference Architecture (draft 1), renumbered to NIST SP 800-200 (draft 2):

https://github.com/usnistgov/CloudSecurityArchitectureToolCSAT/blob/master/Documents/NIST\%20SP\%20800-200-

SRA_DRAFT_20180414.pdf 
[11] Zawoad S, Hasan R, (2013) Digital Forensics in the Cloud, The Journal of Defense Software Engineering (CrossTalk), Vol. 26, No 5, pp. 17-20, Sept 2013.

[12] Zawoad S, Hasan R, (2012) Towards Building Proofs of Past Data Possession in Cloud Forensics, Academy of Science and Engineering Journal, Vol. 1, Issue 4, pp. 195-207.

[13] Zimmerman S, Glavach D, (2011) Cyber Forensics in the Cloud. Information Assurance Technology Analysis Center (IATAC), IA newsletter, Vol 14, No 1, Winter 2011.

[14] Corbin K, (2013) Economic Impact of Cyber Espionage and IP Theft Hits U.S. Businesses Hard, CIO.com, July 2013. http://www.cio.com/article/736132/Economic_Impact_of_Cyber_Espionage_and_IP Theft Hits_U.S._Businesses_Hard

[15] Zatyko K, Bay J, (2012) The Digital Forensics Cyber Exchange Principle, Forensics Magazine. 81. 13-15.

[16] SWGDE Digital and Multimedia Evidence (Digital Forensics) as a Forensic Science Discipline, Version 2.0, September 5, 2014. https://drive.google.com/file/d/1OBux0n7VZQe7HSgObwAtmhz5LgwvX0oY/view

[17] SWGDE Digital and Multimedia Evidence Glossary, Version 3.0, June 23, 2016. https://drive.google.com/file/d/1ZZwOqgVOWo6qDeoJqv6VKafY2i1RJI2B/view

[18] Computer Forensics: Digital Forensic Analysis Methodology. January 2008, Volume 56, number 1, Department of Justice, USA. https://www.justice.gov/sites/default/files/usao/legacy/2008/02/04/usab5601.pdf

[19] ISO/IEC 2382-1, Information technology - Vocabulary - Part 1: Fundamental terms, 1993. https://www.iso.org/standard/7229.html

[20] Scarfone K, Souppaya M, Hoffman P (2011) Guide to Security for Full Virtualization Technologies. (National Institute of Standards and Technology, Gaithersburg, MD), NIST Special Publication (SP) 800-125. https://doi.org/10.6028/NIST.SP.800-125

[21] Carrier BD, (2006) Risks of live digital forensic analysis. Communications of the ACM Volume 49, No 2, , 56-61, Feb. 2006, http://doi.acm.org/10.1145/1113034.1113069.

[22] Bilby D, (2006) Low Down and Dirty: Anti-Forensic Rootkits. Fourth Annual RuxCon Conference (RuxCon 2006), Sydney, Australia.

[23] Lu R, Lin X, Liang X, Shen XS, (2010) Secure provenance: the essential of bread and butter of data forensics in cloud computing. In Proceedings of the 5th ACM Symposium on Information, Computer and Communications Security (ASIACCS 10), ACM, pp. 282-292. 
[24] Ruan K, (2013) Cloud forensics definitions and critical criteria for cloud forensic capability: an overview of survey results, Digital Investigation, March 2013.

[25] Spyridopoulos T, Katos V, (2012) Data Recovery Strategies for Cloud Environments, Cybercrime and Cloud Forensics: Applications for Investigation Processes, Ed. Ruan K, IGI Global, December 2012.

[26] Fowler B, (2009) Securing a Virtual Environment, http://www.infosecwriters.com/text_resources/pdf/BFowler_VIrtual_Environment.pdf

[27] Gonsowski D, (2012) Compliance in the Cloud and Implications on Electronic Discovery, Cybercrime and Cloud Forensics: Applications for Investigation Processes, Ed. Ruan K, IGI Global, December 2012.

[28] Grivas SG, Kumar TU, Wache H, (2010) Cloud Broker: Bringing Intelligence into the Cloud - An Event-based Approach, IEEE 3rd International Conference on Cloud Computing, pp. 544-545.

[29] Ruan K, Carthy J, (2012) Cloud Computing Reference Architecture and its Forensic Implications: a Preliminary Analysis, Proceedings of the 4th International Conference on Digital Forensics \& Cyber Crime, Springer Lecture Notes, October 25-26, 2012 Lafayette, Indiana, USA.

[30] Mapping the Forensic Standard ISO/IEC 27037 to Cloud Computing, Cloud Security Alliance, Incident Management and Forensics Working Group, June 2013. https://downloads.cloudsecurityalliance.org/initiatives/imf/Mapping-the-ForensicStandard-ISO-IEC-27037-to-Cloud-Computing.pdf

[31] Ruan K, James IJ, Carthy J, Kechadi T, (2012) Key Terms for Service Level Agreement to Support Cloud Forensics, Advances in Digital Forensics VIII, Springer, pp. 201-212.

[32] Cohen F, (2012) Challenges to Digital Forensic Evidence in the Cloud, Cybercrime and Cloud Forensics: Applications for Investigation Processes, Ed. Ruan K, IGI Global, December 2012.

[33] Grispos G, Storer T, Glisson W, (2012) Calm before the storm: the challenges of cloud computing in digital forensics. International Journal of Digital Crime and Forensics, 4 (2), pp. 28-48.

[34] Marty R, (2011) Cloud application logging for forensics, ACM Proc., Symposium on Applied Computing (SAC11), Taichung, Taiwan. ACM, pp. 178-184, March 2011.

[35] Reilly D, Wren C, Berry T, (2011) Cloud Computing: Pros and Cons for Computer Forensic Investigators. International Journal Multimedia and Image Processing (IJMIP), Volume 1, Issue 1, March 2011.

[36] Ruan K, (2013) Designing a Forensic-enabling Cloud Ecosystem, Cybercrime and Cloud Forensics: Applications for Investigation Processes, Ed. Ruan K, IGI Global, December 2013. 
[37] Anderson J, Rainie L, (2010) The future of cloud computing, Pew Research Center, https://www.pewresearch.org/internet/2010/06/11/the-future-of-cloud-computing.

[38] Almulla S, Iraqi Y, Jones A, (2013) Cloud forensics: A research perspective, 9th International Conference on Innovations in Information Technology (IIT).

[39] Crosbie M, (2013) Hack the Cloud: Ethical Hacking and Cloud Forensics, Cybercrime and Cloud Forensics: Applications for Investigation Processes, Ed. Ruan K, IGI Global, December 2013.

[40] Anderson R, Barton C, Bohme R, Clayton R, van Eeten JG, Levi M, Moore T, Savage S, (2012) Measuring the Cost of Cybercrime, Workshop on the Economics of Information Security (WEIS).

http://weis2012.econinfosec.org/papers/Anderson WEIS2012.pdf

[41] EC Council (2017) Ethical Hacking and Countermeasures: Attack Phases. $2^{\text {nd }}$ Edition. EC-Council Press.

[42] Lemos R, (2010) Cloud-Based Denial Of Service Attacks Looming, Researchers Say, DEFCON 2010. https://www.darkreading.com/attacks-breaches/cloud-based-denialof-service-attacks-looming-researchers-say/d/d-id/1134121

[43] Ruan K, Carthy J, (2012) Cloud Forensic Maturity Model, Proceedings of the 4th International Conference on Digital Forensics \& Cyber Crime, Springer Lecture Notes, October 25-26, Lafayette, Indiana, USA.

[44] Decker M, Kruse W, Long B, Kelly G, (2011) Dispelling Common Myths of "Live Digital Forensics," http://dfcb.org/wp-content/uploads/2018/05/myth-of-liveforensics.pdf

[45] Barrett D, (2013) Security Architecture and Forensic Awareness in Virtualized Environments, Cybercrime and Cloud Forensics: Applications for Investigation Processes, Ed. Ruan K, IGI Global, December 2013.

[46] Kortchinsky K, (2009) CLOUDBURST: A VMware Guest to Host Escape Story, BlackHat USA 2009, Las Vegas, https://www.blackhat.com/presentations/bh-usa09/KORTCHINSKY/BHUSA09-Kortchinsky-Cloudburst-SLIDES.pdf

[47] Adams R, (2012) The Emergence of Cloud Storage and Need for a New Digital Forensic Process Model, Cybercrime and Cloud Forensics: Applications for Investigation Processes, Ed., IGI Global, 2012.

[48] Chen Y, Paxson V, Katz RH, (2010) What's new about cloud computing security. Electrical Engineering and Computer Sciences, University of California at Berkeley, Technical Report No. UCB/EECS-2010-5, January 20, 2010, http://www.eecs.berkeley.edu/Pubs/TechRpts/2010/EECS-2010-5.html

[49] Dykstra J, Sherman AT, (2011) Understanding Issues in Cloud Forensics: Two Hypothetical Case Studies. Proceedings of the ADFSL Conference on Digital Forensics Security and Law, ASDFL, pp. 191-206. 
[50] Choo KR, (2010) Cloud computing: Challenges and future directions. Trends \& Issues in Crime and Criminal Justice, No 400: 1-6, Canberra: Australian Institute of Criminology. https://www.aic.gov.au/publications/tandi/tandi400

[51] Kaufman L, (2010) Can public-cloud security meet its unique challenges? Security Privacy, IEEE 8, 4, pp. 55-57, July-Aug 2010.

[52] Orton I, Alva A, Endicott-Popovsky B, (2013) Legal Process and Requirements for Cloud Forensic Investigations, Cybercrime and Cloud Forensics: Applications for Investigation Processes, Ed. Ruan K, IGI Global, December 2013.

[53] Dykstra J, Sherman AT, (2013) Design and implementation of FROST: Digital forensic tools for the OpenStack cloud computing platform, Digital Investigation, Volume 10, Supplement, pp. S87-S95, August 2013, https://www.sciencedirect.com/science/article/pii/S174228761300056X

[54] Dykstra J, (2012) Seizing Electronic Evidence from Cloud Computing Environments, Cybercrime and Cloud Forensics: Applications for Investigation Processes, IGI Global, December 2012.

[55] Dykstra J, Riehl D, (2012) Forensic Collection of Electronic Evidence from Infrastructure-as-a-Service Cloud Computing, Richmond Journal of Law and Technology, http://jolt.richmond.edu/wordpress/?p=463 .

[56] Muniswamy-Reddy K, Macko P, Seltzer M, (2010) Provenance for the cloud. In Proceedings of the 8th USENIX conference on File and storage technologies (FAST10). USENIX Association, Berkeley, CA, USA, 15-14, 2010.

[57] Hay B, Nance, K Bishop, M. Storm clouds rising: Security challenges for IaaS cloud computing. 44th Hawaii International Conference on system Sciences-HICSS 2011, Kauai, Hawaii USA, pp. 1-7, 2011.

[58] Birk D, Wegener C, (2011) Technical Issues of Forensic Investigations in Cloud Computing Environments, IEEE Sixth International Workshop on Systematic Approaches to Digital Forensic Engineering (SADFE), pp.1-10, 26 May 2011.

[59] Kirsten, FB, Convery N, (2011) Storing Information in the Cloud - A Research Project. Journal of the Society of Archivists, 32:2, 221-239, https://www.tandfonline.com/doi/abs/10.1080/00379816.2011.619693

[60] Dykstra J, Sherman AT, (2012) Acquiring Forensic Evidence from Infrastructure-as-aService Cloud Computing: Exploring and Evaluating Tools, Trust, and Techniques, Digital Investigation; 9, Supplement: S90-S98. The Proceedings of the Twelfth Annual DFRWS C.

[61] James JI, Shosha AF, Gladyshev P, (2013) Digital Forensic Investigation and Cloud Computing, Cybercrime and Cloud Forensics: Applications for Investigation Processes, Ed. Ruan K, IGI Global, December 2013. 
[62] Grobauer B, Schreck T, (2010) Towards Incident Handling in the Cloud: Challenges and Approaches, CCSW '10: Proceedings of the 2010 ACM workshop on Cloud computing security workshop October 2010, 77-86 https://doi.org/10.1145/1866835.1866850

[63] Anthes G, (2010) Security in the cloud, Communications of the ACM 53(11): 16-18, November 2010, DOI: 10.1145/1839676.1839683

[64] Creeger M, (2010) Moving to the Edge: A CTO Roundtable on Network Virtualization. Communications of the ACM, August 2010. https://doi.org/10.1145/1787234.1787251

[65] Convery N, (2010) Cloud computing toolkit: guidance for outsourcing information storage to the cloud. http://www.archives.org.uk/images/documents/Cloud_Computing_Toolkit-2.pdf

[66] CIO Council \& Chief Acquisition Officers Council, (2012) Creating Effective Cloud Computing Contracts for the Federal Government. https://s3.amazonaws.com/sitesusa/wpcontent/uploads/sites/1151/2016/10/cloudbestpractices.pdf

[67] Cloud Security Alliance, Legal Information Center, (2013) What Rules Apply to Government Access to Data Held by US Cloud Service Providers. https://cloudsecurityalliance.org/artifacts/government-access-to-data-held-by-uscloud-service-providers/

[68] Hooper C, Martini B, Choo KR, (2013) Cloud computing and its implications for cybercrime investigations. In: Australia, Computer Law and Security Review 29(2): $152-163$.

[69] Cisco Visual Networking Index: Global Mobile Data Traffic Forecast Update 20152020, February 2016. https://www.cisco.com/c/dam/m/en in/innovation/enterprise/assets/mobile-whitepaper-c11-520862.pdf.

[70] Pearson S, Yee G, (2012) Privacy, Security and Trust in Cloud Computing, In: Privacy and Security for Cloud Computing, Computer Communications and Networks, Springer.

[71] Ferguson-Boucher K, Endicott-Popovsky B, (2013) Forensic Readiness in the Cloud: Integrating Records Management and Digital Forensics. Cybercrime and Cloud Forensics: Applications for Investigation Processes, IGI Global, https://www.igiglobal.com/chapter/forensic-readiness-cloud-frc/73960

[72] Quick Q, Martini B, Choo KR, (2014) Cloud Storage Forensics, Syngress Publishing / Elsevier.

[73] Martini B, Choo KR, (2011) An integrated conceptual digital forensic framework for cloud computing, Digital Investigation 9(2), pp. 71-80. 
[74] Manral B, Somani G, Choo KR, Conti M, Gaur MS, (2020) A Systematic Survey on Cloud Forensics Challenges, Solutions, and Future Directions, ACM Computing Surveys 52(6): 124:1-124:38, https://doi.org/10.1145/3361216 


\section{Appendix A: Acronyms}

Selected acronyms and abbreviations used in the document are defined below.
API
Application Programming Interface
BNA
Broad Network Access
BOSS Business Operation Support Services
CIO Chief Information Officer
DDoS Distributed Denial of Service
DHCP Dynamic Host Configuration Protocol
EC2 Elastic Compute Cloud
FC Forensic Challenge
G Generic
G8 Group of Eight
IaaS Infrastructure as a Service
IATAC Information Assurance Technology Analysis Center
IEEE Institute of Electrical and Electronics Engineers
INTERPOL International Criminal Police Organization
IP Internet Protocol
ITL Information Technology Laboratory
ITOS Information Technology Operation and Support
MS Measured Service
N/A Not Applicable
NCC FSWG NIST Cloud Computing Forensic Science Working Group
NCCP NIST Cloud Computing Program
NIST National Institute of Standards and Technology
NISTIR NIST Interagency or Internal Report
NTP Network Time Protocol
NTTAA National Technology Transfer and Advancement Act
OD On-Demand Self-Service 
OMB Office of Management and Budget

PaaS Platform as a Service

PII Personally Identifiable Information

PSK Pre-Shared Key

Q Quasi

RAM Random Access Memory

RE Rapid Elasticity

RP Resource Pooling

S Specific

SaaS Software as a Service

S\&RM Security and Risk Management

SOP Standard Operating Procedure

SP Special Publication

SPAN Switched Port Analyzer

SRA Security Reference Architecture

TAPS Test Access Port

TCP Transmission Control Protocol

US United States

USB Universal Serial Bus

USG United States Government

UTC Coordinated Universal Time

VM Virtual Machine

VMM Virtual Machine Monitor

WPA Wi-Fi Protected Access 


\section{Appendix B: Glossary}

Challenge

Cloud Auditor

Cloud Broker

Cloud Carrier

Cloud computing

Cloud Consumer

Cloud Provider

Digital forensics

First responder

Forensic science

Forensic examiner

Imaging
For this paper, a currently difficult or impossible task that is either unique to cloud computing or exacerbated by it

A party that can conduct an independent assessment of cloud services, information system operations, performance, and security of the cloud implementation [8]

An entity that manages the use, performance, and delivery of cloud services and negotiates relationships between Cloud Providers and Cloud Consumers [8]

An intermediary that provides connectivity and transport of cloud services from Cloud Providers to Cloud Consumers [8]

A model for enabling ubiquitous, convenient, on-demand network access to a shared pool of configurable computing resources (e.g., networks, servers, storage, applications, and services) that can be rapidly provisioned and released with minimal management effort or service Provider interaction. This cloud model is composed of five essential characteristics, three service models, and four deployment models [3]

A person or organization that maintains a business relationship with and uses service from Cloud Providers [8]

The entity (a person or an organization) responsible for making a service available to interested parties [8]

The process used to acquire, preserve, analyze, and report on evidence using scientific methods that are demonstrably reliable, accurate, and repeatable such that it may be used in judicial proceedings [16]

A person who provides a rapid initial response to any IT incident or event that may require further investigation. Examples of such events include security threats, cyber-attacks and other illegal activities.

The use or application of scientific knowledge to a point of law, especially as it applies to the investigation of crime [16]

A person who is an expert in acquiring, preserving, analyzing, and presenting digital evidence from computers and other digital media. This evidence may be related to computer-based and non-cyber crimes, including security threats, cyber-attacks, and other illegal activities.

The process used to obtain a bit by bit copy of data residing on the original electronic media; allows the investigator to review a duplicate of the original evidence while preserving that evidence [18] 
NISTIR 8006

Virtual machine

Virtualization
A virtual data processing system that appears to be at the disposal of a particular user but whose functions are accomplished by sharing the resources of a real data processing system [19]

The simulation of the software and/or hardware upon which other software runs; this simulated environment is called a virtual machine (Adapted from [20]) 
Annex A: Cloud Forensic Challenges

\section{Table 1: Cloud forensic challenges}

The following table captures, in no particular order, the cloud-specific forensic challenges identified through extensive literature research.

\begin{tabular}{|c|c|c|c|c|}
\hline FC ID & Short Title & Challenge & Description & Result of Overcoming Challenge \\
\hline FC-01 & $\begin{array}{l}\text { Deletion in the } \\
\text { cloud }\end{array}$ & $\begin{array}{l}\text { Recovering data } \\
\text { deleted from the } \\
\text { cloud (by either } \\
\text { the Provider, } \\
\text { Consumer, or } \\
\text { attacker) and } \\
\text { attributing that } \\
\text { data to a specific } \\
\text { user }\end{array}$ & $\begin{array}{l}\text { Deletion in the cloud is often based on the } \\
\text { deletion of nodes pointing to information in } \\
\text { virtual instances. Pathways for retrieval of the } \\
\text { deleted information are dependent on cloud } \\
\text { Providers offering sufficiently sophisticated } \\
\text { mechanisms for access. } \\
\text { Once the data is recovered, it remains a } \\
\text { challenge to attribute specific data items to an } \\
\text { individual user given the fact that cloud-based } \\
\text { storage is a shared service in a multi-tenant } \\
\text { environment. }\end{array}$ & $\begin{array}{l}\text { If this challenge were overcome, it } \\
\text { would be easier to recover deleted } \\
\text { data and to attribute that recovered } \\
\text { data to a specific user. }\end{array}$ \\
\hline FC-02 & $\begin{array}{l}\text { Recovering } \\
\text { overwritten data }\end{array}$ & $\begin{array}{l}\text { Recovery of } \\
\text { deleted data that } \\
\text { has been } \\
\text { overwritten by } \\
\text { another user in a } \\
\text { shared virtual } \\
\text { environment }\end{array}$ & $\begin{array}{l}\text { Recovery of data marked as deleted (i.e., for } \\
\text { which the nodes pointing to it are deleted) is } \\
\text { difficult if the data is overwritten by another } \\
\text { user in a shared virtual environment. } \\
\text { Note: Data can be overwritten by the same } \\
\text { user or another user. If the latter, attributing } \\
\text { ownership is difficult. }\end{array}$ & $\begin{array}{l}\text { If this challenge were overcome, it } \\
\text { would be easier to recover deleted } \\
\text { data that has been overwritten and to } \\
\text { attribute that recovered data to a } \\
\text { specific user. }\end{array}$ \\
\hline
\end{tabular}




\begin{tabular}{|c|c|c|c|c|}
\hline FC ID & Short Title & Challenge & Description & Result of Overcoming Challenge \\
\hline FC-03 & $\begin{array}{l}\text { Evidence } \\
\text { correlation }\end{array}$ & $\begin{array}{l}\text { Evidence } \\
\text { correlation across } \\
\text { cloud Providers }\end{array}$ & $\begin{array}{l}\text { Correlation of activities across multiple cloud } \\
\text { Providers is a challenge. A primary reason is } \\
\text { lack of interoperability. }\end{array}$ & $\begin{array}{l}\text { If this challenge were overcome, the } \\
\text { investigator could correlate evidence } \\
\text { from different cloud Providers. }\end{array}$ \\
\hline FC-04 & $\begin{array}{l}\text { Reconstructing } \\
\text { virtual storage }\end{array}$ & $\begin{array}{l}\text { Reconstruction of } \\
\text { virtual storage in } \\
\text { cloud } \\
\text { environments from } \\
\text { physical disk } \\
\text { images }\end{array}$ & $\begin{array}{l}\text { In some cloud environments, imaging of } \\
\text { media has an added level of complexity that } \\
\text { could cause damage to the original media. }\end{array}$ & $\begin{array}{l}\text { If this challenge were overcome, an } \\
\text { investigator could reconstruct virtual } \\
\text { storage from all of the relevant } \\
\text { physical disk images, making it } \\
\text { easier to produce reliable forensic } \\
\text { evidence associated with the data } \\
\text { stored on the physical disks. }\end{array}$ \\
\hline FC-05 & $\begin{array}{l}\text { Timestamp } \\
\text { synchronization }\end{array}$ & $\begin{array}{l}\text { Synchronization of } \\
\text { timestamps }\end{array}$ & $\begin{array}{l}\text { Accurate time synchronization has always } \\
\text { been an issue in network forensics and is made } \\
\text { all the more challenging in a cloud } \\
\text { environment since timestamps must be } \\
\text { synchronized across multiple physical } \\
\text { machines that are spread across multiple } \\
\text { geographical regions between the cloud } \\
\text { infrastructure and remote web clients, } \\
\text { including numerous end points. }\end{array}$ & $\begin{array}{l}\text { If this challenge were overcome, it } \\
\text { would be possible to achieve } \\
\text { timestamp synchronization across the } \\
\text { cloud environment relevant to the } \\
\text { investigation (as may be needed for, } \\
\text { e.g., correlation of evidence and } \\
\text { timeline determination). }\end{array}$ \\
\hline
\end{tabular}




\begin{tabular}{|c|c|c|c|c|}
\hline FC ID & Short Title & Challenge & Description & Result of Overcoming Challenge \\
\hline FC-06 & $\begin{array}{l}\text { Log format } \\
\text { unification }\end{array}$ & $\begin{array}{l}\text { Unification of } \log \\
\text { formats }\end{array}$ & $\begin{array}{l}\text { Unified means of collecting and exporting log } \\
\text { data have been a traditional issue in network } \\
\text { forensics. This challenge is exacerbated in the } \\
\text { cloud because it is extremely difficult to unify } \\
\text { log formats or make them convertible to each } \\
\text { other from the massive resources available in } \\
\text { the cloud without a standardized interface and } \\
\text { export format. Furthermore, proprietary or } \\
\text { unusual log formats of one party can become } \\
\text { major roadblocks in joint investigations. }\end{array}$ & $\begin{array}{l}\text { If this challenge were overcome, the } \\
\text { investigator could unify log formats } \\
\text { (as may be needed for, e.g., evidence } \\
\text { correlation or log analysis). }\end{array}$ \\
\hline FC-07 & Use of metadata & Use of metadata & $\begin{array}{l}\text { The use of metadata (as an authentication } \\
\text { method) may be in peril since common fields } \\
\text { (e.g., creation date, last modified date, last } \\
\text { accessed date, etc.) may be changed as the data } \\
\text { is migrated to and within the cloud. Metadata } \\
\text { may also be changed during the collection } \\
\text { process, giving rise to both authentication } \\
\text { challenges and spoliation concerns. Entities } \\
\text { that maintain information in the cloud should } \\
\text { consider the impact of the cloud on metadata, } \\
\text { understand what metadata the cloud Provider } \\
\text { preserves, and identify whether it can be } \\
\text { readily accessed for e-discovery purposes. } \\
\text { However, cloud computing can offer } \\
\text { additional metadata that would not be } \\
\text { available in non-cloud cases (e.g., login events } \\
\text { to the cloud environment, versioning } \\
\text { information, and file integrity data). }\end{array}$ & $\begin{array}{l}\text { If this challenge were overcome, an } \\
\text { investigator would have access to } \\
\text { persistent metadata fields (as may be } \\
\text { needed to, e.g., highlight usage } \\
\text { patterns, establish timelines, event } \\
\text { correlation, and point to gaps in the } \\
\text { data and events). } \\
\text { Note: authentication is not } \\
\text { appropriate for this challenge. }\end{array}$ \\
\hline
\end{tabular}




\begin{tabular}{|c|c|c|c|c|}
\hline FC ID & Short Title & Challenge & Description & Result of Overcoming Challenge \\
\hline FC-08 & Log capture & $\begin{array}{l}\text { Capture and } \\
\text { timeline analysis } \\
\text { of logs }\end{array}$ & $\begin{array}{l}\text { Log capture is difficult in cloud environments } \\
\text { and complicates forensic timeline analysis, } \\
\text { review, and event correlation for DHCP log } \\
\text { data. }\end{array}$ & $\begin{array}{l}\text { If this challenge were overcome, the } \\
\text { investigator could perform forensic } \\
\text { timeline analysis of network logs } \\
\text { involving dynamically assigned IP } \\
\text { addresses. }\end{array}$ \\
\hline FC-09 & $\begin{array}{l}\text { Interoperability } \\
\text { issues among } \\
\text { Providers }\end{array}$ & $\begin{array}{l}\text { No interoperability } \\
\text { among Providers }\end{array}$ & $\begin{array}{l}\text { Identifying commonalities and major } \\
\text { differences between architectures can lead to } \\
\text { more efficient, effective, and consistent } \\
\text { collection of forensic evidence. }\end{array}$ & $\begin{array}{l}\text { If this challenge were overcome, } \\
\text { there would be validated standards } \\
\text { and specifications that support } \\
\text { interoperable forensic techniques and } \\
\text { tools (i.e., interoperable across } \\
\text { different Providers). This would } \\
\text { provide more reliable, consistent, and } \\
\text { comprehensive forensic tools. }\end{array}$ \\
\hline FC- $11^{8}$ & $\begin{array}{l}\text { No single } \\
\text { source for } \\
\text { criminals }\end{array}$ & $\begin{array}{l}\text { No single point of } \\
\text { failure for } \\
\text { criminals }\end{array}$ & $\begin{array}{l}\text { There is no single source that would allow } \\
\text { criminals to be caught in a straightforward } \\
\text { manner, no one computer in a group that holds } \\
\text { all the data necessary for the forensic } \\
\text { investigator to reconstruct the information } \\
\text { about the crime. A criminal organization can } \\
\text { choose one cloud Provider as a storage } \\
\text { solution, obtain compute services from a } \\
\text { second cloud Provider, and route all of their } \\
\text { communications through a third Provider (e.g., } \\
\text { an email provider). }\end{array}$ & $\begin{array}{l}\text { If this challenge were overcome, the } \\
\text { investigator can link all accounts of } \\
\text { the same user on different clouds, } \\
\text { allowing for the ability to acquire, } \\
\text { combine, and analyze forensic data } \\
\text { from multiple Providers used by the } \\
\text { user. }\end{array}$ \\
\hline
\end{tabular}

${ }^{8}$ FC-10, FC-20, and FC-57 are deleted from the final document because the Working Group considered them to be obsolete challenges at the time of publication. Subsequent work derived from this document used the initial FC numbers, so the initial numbering system has been maintained for compatibility and traceability. 


\begin{tabular}{|c|c|c|c|c|}
\hline FC ID & Short Title & Challenge & Description & Result of Overcoming Challenge \\
\hline FC-12 & $\begin{array}{l}\text { Detection of the } \\
\text { malicious act }\end{array}$ & $\begin{array}{l}\text { Detection of the } \\
\text { malicious act }\end{array}$ & $\begin{array}{l}\text { Attacks on computer systems are typically } \\
\text { performed through sequences of incremental } \\
\text { steps where each step in an attack exploits } \\
\text { what would appear to be a small vulnerability. } \\
\text { This steppingstone approach to exploitation } \\
\text { also applies to the cloud space. Forensic } \\
\text { investigators will not find a single ah-ha } \\
\text { moment where an attack is launched and a } \\
\text { system is compromised. Instead, they will } \\
\text { likely find a series of small changes made } \\
\text { across dozens of systems and applications that } \\
\text { enable an attacker to compromise the chosen } \\
\text { target. }\end{array}$ & $\begin{array}{l}\text { If this challenge were overcome, it } \\
\text { would be easier and faster to detect a } \\
\text { malicious act. }\end{array}$ \\
\hline FC-13 & $\begin{array}{l}\text { Criminals' } \\
\text { access to low- } \\
\text { cost computing } \\
\text { power }\end{array}$ & $\begin{array}{l}\text { The cloud offers } \\
\text { computing power } \\
\text { that would } \\
\text { otherwise be } \\
\text { unavailable to } \\
\text { criminals with } \\
\text { small budgets } \\
\text { and/or limited } \\
\text { resources }\end{array}$ & $\begin{array}{l}\text { Cloud computing offers computing power that } \\
\text { would otherwise be unavailable to criminals } \\
\text { with small budgets and/or limited resources. } \\
\text { Google's AppEngine was used as a command- } \\
\text { and-control network for a botnet in } 2009 \text {. } \\
\text { Password cracking the cloud is already offered } \\
\text { as a service by one security firm, and the } \\
\text { Amazon EC2 computer service was used by a } \\
\text { security researcher to crack WiFi WPA-PSK } \\
\text { passwords. }\end{array}$ & $\begin{array}{l}\text { If this challenge were overcome, } \\
\text { criminals would not have easy access } \\
\text { to cloud computing for criminal } \\
\text { activities. }\end{array}$ \\
\hline
\end{tabular}




\begin{tabular}{|c|c|c|c|c|}
\hline FC ID & Short Title & Challenge & Description & Result of Overcoming Challenge \\
\hline FC-14 & $\begin{array}{l}\text { Real-time } \\
\text { investigation } \\
\text { intelligence } \\
\text { processes not } \\
\text { possible }\end{array}$ & $\begin{array}{l}\text { Intelligence } \\
\text { processes for real- } \\
\text { time investigation } \\
\text { are often not } \\
\text { possible in the } \\
\text { cloud environment }\end{array}$ & $\begin{array}{l}\text { Data that is not stored in storage media cannot } \\
\text { be seized; it can only be collected in real time } \\
\text { by placing sensors into the real-time } \\
\text { environment. The manner in which such } \\
\text { evidence is identified must be different from } \\
\text { that in which evidence resides in a desktop or } \\
\text { within a disk. This sort of evidence must be } \\
\text { identified by an intelligence process and, in } \\
\text { many cases, special legal means must be } \\
\text { applied to collect it. } \\
\text { In most cloud environments, such intelligence } \\
\text { is hard to come by, and most Providers do not } \\
\text { want to reveal the specifics of their operations. } \\
\text { Such operations often change quickly with } \\
\text { time, and many parties may be involved. For } \\
\text { example, a cloud infrastructure may be } \\
\text { composed of leased time on hundreds of } \\
\text { systems around the globe, owned and operated } \\
\text { by scores of different Providers. With records } \\
\text { spread across such an infrastructure, even } \\
\text { knowing where to look to place sensors is } \\
\text { enormously problematic. }\end{array}$ & $\begin{array}{l}\text { If this challenge were overcome, the } \\
\text { investigator could collect real-time } \\
\text { intelligence about evidence, allowing } \\
\text { the ability to perform real-time } \\
\text { forensic investigation (i.e., collect } \\
\text { data and forensic artifacts in a real- } \\
\text { time, rapidly changing cloud } \\
\text { environment). }\end{array}$ \\
\hline
\end{tabular}




\begin{tabular}{|c|c|c|c|c|}
\hline FC ID & Short Title & Challenge & Description & Result of Overcoming Challenge \\
\hline FC-15 & $\begin{array}{l}\text { Malicious code } \\
\text { may circumvent } \\
\text { VM isolation } \\
\text { methods }\end{array}$ & $\begin{array}{l}\text { Malicious code } \\
\text { may circumvent } \\
\text { virtual machine } \\
\text { isolation methods } \\
\text { and interfere with } \\
\text { the hypervisor or } \\
\text { other guest virtual } \\
\text { machines }\end{array}$ & $\begin{array}{l}\text { Vulnerabilities in server virtualization allow } \\
\text { an attacker to escape from a guest virtual } \\
\text { machine to another guest or to the hypervisor } \\
\text { itself. Ensuring that a compromised virtual } \\
\text { machine stays isolated requires comprehensive } \\
\text { security in the hypervisor and the software that } \\
\text { interacts with the virtual machine. }\end{array}$ & $\begin{array}{l}\text { If this forensic challenge were } \\
\text { overcome, it would make forensic } \\
\text { investigations easier by effectively } \\
\text { tracing the movement and isolating } \\
\text { the location of malware that has } \\
\text { transitioned from its original } \\
\text { infection point to other areas of the } \\
\text { virtual environment. }\end{array}$ \\
\hline FC-16 & $\begin{array}{l}\text { Errors in cloud } \\
\text { management } \\
\text { portal } \\
\text { configurations }\end{array}$ & $\begin{array}{l}\text { Configuration } \\
\text { errors in cloud } \\
\text { management } \\
\text { portals may result } \\
\text { in an unauthorized } \\
\text { user being able to } \\
\text { reconfigure or } \\
\text { delete another } \\
\text { user's cloud } \\
\text { computing } \\
\text { platform }\end{array}$ & $\begin{array}{l}\text { Vulnerabilities in management portal } \\
\text { applications provided by cloud Providers may } \\
\text { be exploited by an unauthorized individual to } \\
\text { gain control, reconfigure, or delete another } \\
\text { cloud tenant's resources or applications. }\end{array}$ & $\begin{array}{l}\text { If this challenge were overcome, it } \\
\text { would be easier for investigators to } \\
\text { confidently attribute all changes that } \\
\text { originate from cloud management } \\
\text { portal applications to a specific user, } \\
\text { resulting in the investigator knowing } \\
\text { when an unauthorized user has } \\
\text { gained control, reconfigured, or } \\
\text { deleted another tenant's resources or } \\
\text { applications. }\end{array}$ \\
\hline FC-17 & $\begin{array}{l}\text { Multiple venues } \\
\text { and } \\
\text { geolocations }\end{array}$ & $\begin{array}{l}\text { Access to } \\
\text { computer and } \\
\text { network resources } \\
\text { involve expanded } \\
\text { scope and, } \\
\text { possibly, more } \\
\text { than one venue } \\
\text { and geolocation }\end{array}$ & $\begin{array}{l}\text { Geolocation unknowns can impact the chain of } \\
\text { custody, finding evidence, and identifying } \\
\text { resources that are required for access to the } \\
\text { system. }\end{array}$ & $\begin{array}{l}\text { If this challenge were overcome, } \\
\text { knowing the location of the venues or } \\
\text { geolocations would make it easier to } \\
\text { find the evidence and identify } \\
\text { resources to maintain the chain of } \\
\text { custody. }\end{array}$ \\
\hline
\end{tabular}




\begin{tabular}{|c|c|c|c|c|}
\hline FC ID & Short Title & Challenge & Description & Result of Overcoming Challenge \\
\hline FC-18 & $\begin{array}{l}\text { Lack of } \\
\text { transparency }\end{array}$ & $\begin{array}{l}\text { Lack of } \\
\text { transparency } \\
\text { triggers lack of } \\
\text { trust and } \\
\text { difficulties of } \\
\text { auditing }\end{array}$ & $\begin{array}{l}\text { The cloud's operational details (architecture } \\
\text { and implementation) aren't transparent to } \\
\text { users. }\end{array}$ & $\begin{array}{l}\text { If this challenge were overcome, the } \\
\text { cloud's operational details would } \\
\text { become more transparent, making it } \\
\text { easier to collect forensic evidence } \\
\text { that is accurate, complete, traceable, } \\
\text { auditable, and forensically sound. }\end{array}$ \\
\hline FC-19 & $\begin{array}{l}\text { Criminals can } \\
\text { hide in the } \\
\text { cloud }\end{array}$ & $\begin{array}{l}\text { The distributed } \\
\text { nature of cloud } \\
\text { computing enables } \\
\text { a criminal } \\
\text { organization to } \\
\text { maintain small } \\
\text { cells of operation } \\
\text { with no one cell } \\
\text { knowing the } \\
\text { identity of any } \\
\text { others }\end{array}$ & $\begin{array}{l}\text { Data partitioning allows each cell in the } \\
\text { criminal organization to preserve its } \\
\text { anonymity while still sharing information on } \\
\text { likely victims and the results of any criminal } \\
\text { activities. Thus, individual members of such } \\
\text { an organization may be unaware of the } \\
\text { identities of other members. }\end{array}$ & $\begin{array}{l}\text { If this challenge were overcome, } \\
\text { cells of the criminal organizations } \\
\text { would be discoverable, making it } \\
\text { easier for the forensic investigator to } \\
\text { identify forensic evidence. }\end{array}$ \\
\hline
\end{tabular}




\begin{tabular}{|c|c|c|c|c|}
\hline FC ID & Short Title & Challenge & Description & Result of Overcoming Challenge \\
\hline $\mathrm{FC}-21^{9}$ & $\begin{array}{l}\text { Potential } \\
\text { evidence } \\
\text { segregation }\end{array}$ & $\begin{array}{l}\text { Segregation of } \\
\text { potential evidence } \\
\text { in a multi-tenant } \\
\text { system }\end{array}$ & $\begin{array}{l}\text { Segregation of forensic data in an } \\
\text { infrastructure shared by multiple users (i.e., } \\
\text { multi-tenant environment) is needed. } \\
\text { Technologies used for provisioning and } \\
\text { deprovisioning resources are constantly being } \\
\text { improved. It is a challenge for cloud service } \\
\text { Providers and law enforcement agencies to } \\
\text { segregate resources during investigations } \\
\text { without breaching the confidentiality of other } \\
\text { tenants who share the infrastructure. }\end{array}$ & $\begin{array}{l}\text { If this challenge were overcome, it } \\
\text { would be easier for the investigator } \\
\text { to access forensic evidence of one } \\
\text { tenant in a way that preserves the } \\
\text { confidentiality/privacy of other } \\
\text { tenants. }\end{array}$ \\
\hline FC-22 & Boundaries & Boundaries & $\begin{array}{l}\text { Because of the elastic nature of cloud } \\
\text { computing and the inherent complications of } \\
\text { multi-tenant environments, system boundaries } \\
\text { are often difficult to define. }\end{array}$ & $\begin{array}{l}\text { If this challenge were overcome, it } \\
\text { would be easier to focus the scope of } \\
\text { the investigation within appropriate } \\
\text { boundaries and ensure that the } \\
\text { forensic information collected is } \\
\text { relevant to the investigation. }\end{array}$ \\
\hline FC-23 & $\begin{array}{l}\text { Secure } \\
\text { provenance }\end{array}$ & Secure provenance & $\begin{array}{l}\text { Provenance is a record of the history of an } \\
\text { item. In the context of cloud computing, } \\
\text { secure provenance refers to establishing the } \\
\text { chronology of ownership, custody, or location } \\
\text { of data. Establishing these characteristics in a } \\
\text { cloud environment is challenging due to multi- } \\
\text { tenancy and the elastic nature of the cloud. }\end{array}$ & $\begin{array}{l}\text { If this challenge were overcome, it } \\
\text { would be easier for the investigator } \\
\text { to guarantee the ownership, custody, } \\
\text { location, or actions taken on forensic } \\
\text { evidence. }\end{array}$ \\
\hline
\end{tabular}

${ }^{9}$ FC-10, FC-20, and FC-57 are deleted from the final document because the Working Group considered them to be obsolete challenges at the time of publication. Subsequent work derived from this document used the initial FC numbers, so the initial numbering system has been maintained for compatibility and traceability. 


\begin{tabular}{|c|c|c|c|c|}
\hline FC ID & Short Title & Challenge & Description & Result of Overcoming Challenge \\
\hline FC-24 & $\begin{array}{l}\text { Data chain of } \\
\text { custody }\end{array}$ & $\begin{array}{l}\text { Chain of custody } \\
\text { of data }\end{array}$ & $\begin{array}{l}\text { Because of the distributed, multi-layered } \\
\text { nature of cloud computing, the chain of } \\
\text { custody of data may be impossible to verify. } \\
\text { Without strict controls, it may be impossible to } \\
\text { determine exactly where the data was stored, } \\
\text { who had access to it, and whether leakage or } \\
\text { contamination of the data was possible. If data } \\
\text { is stored in a cloud to which multiple users and } \\
\text { cloud service Providers potentially have } \\
\text { access, associating the data to the subject } \\
\text { beyond a reasonable doubt is a challenge. }\end{array}$ & $\begin{array}{l}\text { If this challenge were overcome, it } \\
\text { would be easier for the investigator } \\
\text { to verify who had continuous } \\
\text { ownership and access to forensic } \\
\text { evidence. }\end{array}$ \\
\hline FC-25 & $\begin{array}{l}\text { Decreased } \\
\text { access and data } \\
\text { control }\end{array}$ & $\begin{array}{l}\text { Decreased access } \\
\text { and control of data } \\
\text { at all levels by } \\
\text { cloud Consumers }\end{array}$ & $\begin{array}{l}\text { In every combination of cloud service and } \\
\text { deployment models, the cloud Consumer faces } \\
\text { the challenge of decreased access to forensic } \\
\text { data. Decreased access to forensic data means } \\
\text { that cloud Consumers generally have little or } \\
\text { no control_or even knowledge - of the } \\
\text { physical locations of their data. In fact, they } \\
\text { may only be able to specify location at a high } \\
\text { level of abstraction, typically as an object or } \\
\text { container. Cloud Providers abstract data } \\
\text { locations from Consumers to facilitate data } \\
\text { movement and replication. }\end{array}$ & $\begin{array}{l}\text { If this challenge were overcome, it } \\
\text { would be easier for investigators who } \\
\text { work through cloud Consumer } \\
\text { accounts to know and obtain access } \\
\text { to physical locations of data in these } \\
\text { accounts. }\end{array}$ \\
\hline
\end{tabular}




\begin{tabular}{|c|c|c|c|c|}
\hline FC ID & Short Title & Challenge & Description & Result of Overcoming Challenge \\
\hline FC-26 & $\begin{array}{l}\text { Chain of } \\
\text { dependencies }\end{array}$ & $\begin{array}{l}\text { Chain of } \\
\text { dependencies in } \\
\text { multiple cloud } \\
\text { systems }\end{array}$ & $\begin{array}{l}\text { Cloud Providers and most cloud applications } \\
\text { often have dependencies on other cloud } \\
\text { Providers. For example, a cloud Provider that } \\
\text { provides an email application (SaaS) may } \\
\text { depend on a third-party Provider to host log } \\
\text { files (i.e., PaaS), which in turn may rely on a } \\
\text { partner who provides the infrastructure to store } \\
\text { log files (IaaS). A cloud forensic investigation } \\
\text { thus requires investigations of each individual } \\
\text { link in the dependency chain. }\end{array}$ & $\begin{array}{l}\text { If this challenge were overcome, it } \\
\text { would be easier for investigators to } \\
\text { obtain evidence in situations } \\
\text { involving multiple chains of } \\
\text { dependencies through multiple cloud } \\
\text { systems. }\end{array}$ \\
\hline FC-27 & $\begin{array}{l}\text { Locating } \\
\text { evidence }\end{array}$ & $\begin{array}{l}\text { Locating evidence } \\
\text { in a large and } \\
\text { changing system }\end{array}$ & $\begin{array}{l}\text { E-discovery is a critical component in cloud } \\
\text { computing and essential for locating data that } \\
\text { may be requested in a subpoena. However, the } \\
\text { time frame for responses and the thoroughness } \\
\text { of the results are questionable due to the lack } \\
\text { of knowledge of all locations of data storage. }\end{array}$ & $\begin{array}{l}\text { If this challenge were overcome, it } \\
\text { would be easier to quickly locate } \\
\text { relevant data in response to an e- } \\
\text { discovery request. }\end{array}$ \\
\hline FC-28 & Data location & Data location & $\begin{array}{l}\text { There are many uncertainties in dealing with } \\
\text { transparency in the cloud and distribution } \\
\text { boundaries for retrieval due to multiple tenants } \\
\text { in multiple data centers. }\end{array}$ & $\begin{array}{l}\text { If this challenge were overcome, data } \\
\text { locations in multiple data centers } \\
\text { would be discoverable, thus making } \\
\text { it easier to retrieve that data. }\end{array}$ \\
\hline
\end{tabular}




\begin{tabular}{|c|c|c|c|c|}
\hline FC ID & Short Title & Challenge & Description & Result of Overcoming Challenge \\
\hline FC-29 & $\begin{array}{l}\text { Imaging, } \\
\text { isolating, and } \\
\text { collecting data }\end{array}$ & $\begin{array}{l}\text { Locating and } \\
\text { collecting cloud- } \\
\text { based data for } \\
\text { forensic } \\
\text { investigations }\end{array}$ & $\begin{array}{l}\text { The mirroring of large volumes of data over } \\
\text { multiple machines in different jurisdictions } \\
\text { and the lack of transparent, real-time } \\
\text { information about data locations introduce } \\
\text { difficulties in collecting data for forensic } \\
\text { investigations. Complicating this challenge is } \\
\text { the fact that the cloud Application } \\
\text { Programming Interfaces (APIs) are often the } \\
\text { only way to access certain data and metadata, } \\
\text { and these APIs are not always developed with } \\
\text { forensic use in mind. }\end{array}$ & $\begin{array}{l}\text { If this challenge were overcome, it } \\
\text { would be easier to locate and collect } \\
\text { constantly moving cloud-based data } \\
\text { for forensic investigations. }\end{array}$ \\
\hline FC-30 & $\begin{array}{l}\text { Data available } \\
\text { for a limited } \\
\text { time }\end{array}$ & $\begin{array}{l}\text { Data associated } \\
\text { with deallocated } \\
\text { virtual machine } \\
\text { (VM) instances } \\
\text { may only be } \\
\text { available for a } \\
\text { limited time }\end{array}$ & $\begin{array}{l}\text { It is difficult to identify the data associated } \\
\text { with removed VM instances. If a new VM } \\
\text { instance is created and either compromised or } \\
\text { used to attack, evidential traces may be } \\
\text { available in the VM. If the VM instance is then } \\
\text { deallocated, investigators would not know } \\
\text { whether evidential traces or the entire VM } \\
\text { instance could be recovered. }\end{array}$ & $\begin{array}{l}\text { If this challenge were overcome, it } \\
\text { would be easier to collect evidential } \\
\text { information from a deallocated VM. }\end{array}$ \\
\hline FC-31 & $\begin{array}{l}\text { Locating } \\
\text { storage media }\end{array}$ & $\begin{array}{l}\text { Identifying storage } \\
\text { media where } \\
\text { artifacts, log files, } \\
\text { and other evidence } \\
\text { may be found }\end{array}$ & $\begin{array}{l}\text { In the cloud, a computer instance may not } \\
\text { have local persistent storage since all storage } \\
\text { occurs through an object store held remotely. }\end{array}$ & $\begin{array}{l}\text { If this challenge were overcome, it } \\
\text { would be easier to identify remote } \\
\text { storage media where relevant } \\
\text { evidence may be found. }\end{array}$ \\
\hline
\end{tabular}




\begin{tabular}{|c|c|c|c|c|}
\hline FC ID & Short Title & Challenge & Description & Result of Overcoming Challenge \\
\hline FC-32 & $\begin{array}{l}\text { Evidence } \\
\text { identification }\end{array}$ & $\begin{array}{l}\text { Sources/traces of } \\
\text { evidence are } \\
\text { generated } \\
\text { differently } \\
\text { compared to non- } \\
\text { cloud } \\
\text { environments and } \\
\text { pose challenges } \\
\text { for evidence } \\
\text { identification }\end{array}$ & $\begin{array}{l}\text { The first step in gathering evidence is } \\
\text { identifying possible sources of evidence for } \\
\text { collection. It is fairly common that identified } \\
\text { evidence includes too little or too much } \\
\text { information. If too much is identified, then } \\
\text { court-mandated search and seizure limitations } \\
\text { may be exceeded. If too little is identified, } \\
\text { exculpatory or inculpatory evidence may be } \\
\text { missed. Commonly missed evidence include } \\
\text { network logs from related network } \\
\text { components. In most cloud computing } \\
\text { environments, most of the evidence and, in } \\
\text { particular, most of the redundant traces are } \\
\text { either not available or are not generated or } \\
\text { stored in the same way as they would be in } \\
\text { traditional non-cloud environments. User } \\
\text { authentication and authorization data and } \\
\text { procedures are typically in the application } \\
\text { rather than in the operating system, so records } \\
\text { tend to be limited to whatever the application } \\
\text { designer decided to do. }\end{array}$ & $\begin{array}{l}\text { If this challenge were overcome, it } \\
\text { would be easier to locate all relevant } \\
\text { forensic data in response to any } \\
\text { forensic request. }\end{array}$ \\
\hline FC-33 & $\begin{array}{l}\text { Dynamic } \\
\text { storage }\end{array}$ & Dynamic storage & $\begin{array}{l}\text { Some cloud Providers dynamically allocate } \\
\text { storage based on the current needs of the user. } \\
\text { As data is deleted from the system, the storage } \\
\text { is re-allocated to optimize data reads and } \\
\text { storage use. }\end{array}$ & $\begin{array}{l}\text { If this challenge were overcome, it } \\
\text { would be easier to recover deleted } \\
\text { data and overwritten deleted data. }\end{array}$ \\
\hline
\end{tabular}




\begin{tabular}{|c|c|c|c|c|}
\hline FC ID & Short Title & Challenge & Description & Result of Overcoming Challenge \\
\hline FC-34 & Live forensics & $\begin{array}{l}\text { Live forensics is } \\
\text { common in cloud } \\
\text { environments, but } \\
\text { many challenges } \\
\text { remain }\end{array}$ & $\begin{array}{l}\text { When evidence is collected in a cloud } \\
\text { environment, the suspect system is still } \\
\text { running, and data is likely changing as it is } \\
\text { being collected. Therefore, after acquisition, it } \\
\text { is impossible for a third party to verify that the } \\
\text { data collected is correct because the data is no } \\
\text { longer the same as it was at the time of } \\
\text { acquisition. When conducting live data } \\
\text { forensics, the processes used in data } \\
\text { acquisition will result in changes to the } \\
\text { system. In order to collect volatile evidence, } \\
\text { the suspect computer must remain on, and the } \\
\text { suspect operating system must be used to } \\
\text { access the needed data. For example, when } \\
\text { retrieving information from RAM, a program } \\
\text { must be loaded into the running memory, } \\
\text { thereby changing its contents. Even inserting a } \\
\text { USB key into a running suspect system will } \\
\text { alter the system. Therefore, live data forensics } \\
\text { usually rely on the suspect system, which [21] } \\
\text { claims cannot be trusted. Rootkits or other } \\
\text { malware in the suspect system can provide } \\
\text { various anti-forensic functions, resulting in } \\
\text { unreliable evidence [22]. Additionally, data } \\
\text { residing in a VM is volatile since after } \\
\text { terminating a VM, all the data may be lost. } \\
\text { Volatile data of a VM includes all of the logs } \\
\text { stored in that VM (e.g., SysLog, registry logs, } \\
\text { and network logs). }\end{array}$ & $\begin{array}{l}\text { If this challenge were overcome, it } \\
\text { would be easier to establish the } \\
\text { veracity and reliability of data } \\
\text { collected in a volatile state from a } \\
\text { live, running cloud computing } \\
\text { system. }\end{array}$ \\
\hline
\end{tabular}




\begin{tabular}{|c|c|c|c|c|}
\hline FC ID & Short Title & Challenge & Description & Result of Overcoming Challenge \\
\hline FC-35 & $\begin{array}{l}\text { Resource } \\
\text { abstraction }\end{array}$ & $\begin{array}{l}\text { Resource } \\
\text { abstraction }\end{array}$ & $\begin{array}{l}\text { In cloud computing, abstract resources are } \\
\text { made available to cloud Consumers. This is } \\
\text { often desirable to Consumers who do not want } \\
\text { to know how the cloud is implemented, but the } \\
\text { lack of transparency makes forensics } \\
\text { challenging. The forensic investigator may } \\
\text { need to know what hardware, hypervisor, or } \\
\text { file system is used in order to accurately } \\
\text { understand the environment. }\end{array}$ & $\begin{array}{l}\text { If this challenge were overcome, it } \\
\text { would make the collection of } \\
\text { evidence in forensic investigations } \\
\text { easier by enabling the investigator to } \\
\text { fully understand (with confidence) all } \\
\text { of the logical and physical aspects of } \\
\text { the system. }\end{array}$ \\
\hline FC-36 & $\begin{array}{l}\text { Application } \\
\text { details are } \\
\text { unavailable }\end{array}$ & $\begin{array}{l}\text { Private and } \\
\text { confidential details } \\
\text { of cloud-based } \\
\text { software/applicati } \\
\text { ons used to } \\
\text { produce records } \\
\text { are typically } \\
\text { unavailable to the } \\
\text { investigator }\end{array}$ & $\begin{array}{l}\text { For example, in a particular criminal case } \\
\text { involving email through cloud service } \\
\text { Providers, the details of how drafts are turned } \\
\text { into deliverable messages were unavailable, } \\
\text { leading to an inability to prove whether or not } \\
\text { a draft was ever sent (and, more obviously, } \\
\text { whether it was ever transmitted or received). }\end{array}$ & $\begin{array}{l}\text { If this challenge were overcome, the } \\
\text { investigator would have access to the } \\
\text { details of application processes, thus } \\
\text { making it easier to obtain relevant } \\
\text { evidence. }\end{array}$ \\
\hline
\end{tabular}




\begin{tabular}{|c|c|c|c|c|}
\hline FC ID & Short Title & Challenge & Description & Result of Overcoming Challenge \\
\hline FC-37 & $\begin{array}{l}\text { Additional } \\
\text { evidence } \\
\text { collection }\end{array}$ & $\begin{array}{l}\text { Additional } \\
\text { collection is often } \\
\text { infeasible in the } \\
\text { cloud }\end{array}$ & $\begin{array}{l}\text { Relevant forensic information is often located } \\
\text { in places not immediately evident from the } \\
\text { original crime scene. In traditional digital } \\
\text { forensics, for cases where evidence is stored } \\
\text { for long periods and can be identified as } \\
\text { missing in a timely fashion, the problem can } \\
\text { usually be mitigated by additional collection. } \\
\text { But in cloud environments, such collection is } \\
\text { often infeasible since specific locations of } \\
\text { content are unknown, the volumes may be } \\
\text { very high, and the protocols and mechanisms } \\
\text { used to exchange information may be non- } \\
\text { standard and poorly or not documented. }\end{array}$ & $\begin{array}{l}\text { If this challenge were overcome, } \\
\text { collecting additional evidence after } \\
\text { initial evidence collection or in areas } \\
\text { not immediately evident from the } \\
\text { original crime scene would be easier } \\
\text { to perform. }\end{array}$ \\
\hline FC-38 & $\begin{array}{l}\text { Imaging the } \\
\text { cloud }\end{array}$ & Imaging the cloud & $\begin{array}{l}\text { Imaging all evidence in the cloud is } \\
\text { impractical while partial imaging may have } \\
\text { legal implications in the presentation to the } \\
\text { court. This leads to the suggestion that forensic } \\
\text { acquisition processes and tools should be an } \\
\text { integrated part of the cloud functionality, } \\
\text { instead of a bolt-on service. }\end{array}$ & $\begin{array}{l}\text { If this challenge were overcome, it } \\
\text { would make forensic investigations } \\
\text { easier by simplifying the process for } \\
\text { cloud imaging while also protecting } \\
\text { the admissibility of evidence by } \\
\text { establishing greater confidence in the } \\
\text { imaging process. }\end{array}$ \\
\hline FC-39 & $\begin{array}{l}\text { Selective data } \\
\text { acquisition }\end{array}$ & $\begin{array}{l}\text { Selective data } \\
\text { acquisition }\end{array}$ & $\begin{array}{l}\text { Selective data acquisition implies a } \\
\text { preliminary analysis or some prior knowledge } \\
\text { to reduce the overall dataset in which an } \\
\text { investigator is interested. Some investigators } \\
\text { focus on data sources that they believe are } \\
\text { likely to provide the richest sources of } \\
\text { information, but justifiable exclusion remains } \\
\text { a challenge. }\end{array}$ & $\begin{array}{l}\text { If this challenge were overcome, it } \\
\text { would be easier to use selective data } \\
\text { acquisition techniques (thus saving } \\
\text { time and resources) to acquire } \\
\text { relevant forensic data. }\end{array}$ \\
\hline
\end{tabular}




\begin{tabular}{|c|c|c|c|c|}
\hline FC ID & Short Title & Challenge & Description & Result of Overcoming Challenge \\
\hline FC-40 & $\begin{array}{l}\text { Cryptographic } \\
\text { key } \\
\text { management }\end{array}$ & $\begin{array}{l}\text { Cryptographic key } \\
\text { management }\end{array}$ & $\begin{array}{l}\text { Difficulties in identifying, maintaining, and } \\
\text { effectively recovering keys makes it easier to } \\
\text { lose the ability to decrypt forensic data stored } \\
\text { in the cloud. }\end{array}$ & $\begin{array}{l}\text { If this challenge were overcome, it } \\
\text { would make forensic investigations } \\
\text { easier by preserving cryptographic } \\
\text { keys that are required in order to } \\
\text { access encrypted forensic evidence. }\end{array}$ \\
\hline FC-41 & $\begin{array}{l}\text { Ambiguous } \\
\text { trust boundaries }\end{array}$ & $\begin{array}{l}\text { Ambiguous trust } \\
\text { boundaries } \\
\text { between users can } \\
\text { cause questionable } \\
\text { data integrity }\end{array}$ & $\begin{array}{l}\text { The use of cloud services, especially of multi- } \\
\text { tenant environments, may increase risk to the } \\
\text { integrity of data, both at rest and during } \\
\text { processing. }\end{array}$ & $\begin{array}{l}\text { If this challenge were overcome, } \\
\text { forensic data would be more reliable, } \\
\text { complete, and attributable to the } \\
\text { correct owner due to better trust } \\
\text { boundaries between users. }\end{array}$ \\
\hline FC-42 & $\begin{array}{l}\text { Data integrity } \\
\text { and evidence } \\
\text { preservation }\end{array}$ & $\begin{array}{l}\text { Responsibility for } \\
\text { quality of } \\
\text { evidence, evidence } \\
\text { admissibility, } \\
\text { faults and failures } \\
\text { in data integrity, } \\
\text { and digital } \\
\text { preservation is } \\
\text { shared among } \\
\text { multiple Actors, } \\
\text { and the } \\
\text { opportunities for } \\
\text { such faults and } \\
\text { failures are higher } \\
\text { in the cloud } \\
\text { context }\end{array}$ & $\begin{array}{l}\text { Digital evidence that is presented in court is } \\
\text { admitted or rejected based on the relative } \\
\text { weights of probative and prejudicial value. } \\
\text { Faults can occur intentionally or accidentally } \\
\text { and consist of missed content, contextual } \\
\text { information, meaning of content, process } \\
\text { elements, relationships, ordering, timing, } \\
\text { location, corroborating content, consistencies, } \\
\text { and inconsistencies. In the cloud, the faults } \\
\text { may extend to multiple computers in multiple } \\
\text { locations under the control of multiple parties. } \\
\text { Thus, opportunities for faults and failures are } \\
\text { extended in the cloud. }\end{array}$ & $\begin{array}{l}\text { If this challenge were overcome, the } \\
\text { faults and failures that contribute to } \\
\text { the quality and integrity of evidence } \\
\text { would decrease in the context of } \\
\text { multiple parties, multiple computers, } \\
\text { multiple locations, etc. }\end{array}$ \\
\hline
\end{tabular}




\begin{tabular}{|c|c|c|c|c|}
\hline FC ID & Short Title & Challenge & Description & Result of Overcoming Challenge \\
\hline FC-43 & Root of trust & Root of trust & $\begin{array}{l}\text { Cloud implementations have multiple layers of } \\
\text { abstraction, from hardware to virtualization to } \\
\text { guest operating systems. The integrity and } \\
\text { trustworthiness of forensic data is dependent } \\
\text { on the cumulative trustworthiness of the layers } \\
\text { that could potentially manipulate or } \\
\text { compromise data integrity. Further, users must } \\
\text { now trust cloud Providers unless integrity can } \\
\text { be guaranteed through some other means (e.g. } \\
\text { cryptographic hashes, hardware roots of trust, } \\
\text { etc.). }\end{array}$ & $\begin{array}{l}\text { If this challenge were overcome, the } \\
\text { integrity and trustworthiness of } \\
\text { forensic data would be improved in } \\
\text { the context of multiple layers of } \\
\text { cloud abstraction and the cumulative } \\
\text { trustworthiness of the layers. }\end{array}$ \\
\hline FC-44 & $\begin{array}{l}\text { Competence } \\
\text { and } \\
\text { trustworthiness }\end{array}$ & $\begin{array}{l}\text { Competence and } \\
\text { trustworthiness of } \\
\text { the cloud Provider } \\
\text { as an effective, } \\
\text { immediate first } \\
\text { responder }\end{array}$ & $\begin{array}{l}\text { When an incident occurs on the side of the } \\
\text { cloud Provider, the Provider may be more } \\
\text { concerned with restoring service than with } \\
\text { preserving evidence. Further, the Provider may } \\
\text { begin its own investigation into an incident } \\
\text { without taking proper precautions to ensure the } \\
\text { integrity of potential evidence. In more severe } \\
\text { cases, Providers may not report or cooperate in } \\
\text { the investigation of incidents for fear of } \\
\text { reputational damage. }\end{array}$ & $\begin{array}{l}\text { If this challenge were overcome, it } \\
\text { would make forensic investigations } \\
\text { easier by ensuring that cloud } \\
\text { Providers treat a compromised cloud } \\
\text { environment as a crime scene in } \\
\text { order to preserve the veracity, } \\
\text { integrity, and admissibility of } \\
\text { essential forensic evidence. }\end{array}$ \\
\hline FC-45 & $\begin{array}{l}\text { Missing terms } \\
\text { in contract or } \\
\text { SLA }\end{array}$ & $\begin{array}{l}\text { Missing terms in } \\
\text { contract or Service } \\
\text { Level Agreement }\end{array}$ & $\begin{array}{l}\text { Requirements that the cloud Provider maintain } \\
\text { and/or produce pertinent evidence within } \\
\text { specified time constraints may not be } \\
\text { explicitly stated in the agreement. }\end{array}$ & $\begin{array}{l}\text { If this challenge were overcome, it } \\
\text { would make forensic investigations } \\
\text { easier by clearly delineating cloud } \\
\text { Provider responsibilities for } \\
\text { preserving and providing timely } \\
\text { access to relevant forensic } \\
\text { information. }\end{array}$ \\
\hline
\end{tabular}




\begin{tabular}{|c|c|c|c|c|}
\hline FC ID & Short Title & Challenge & Description & Result of Overcoming Challenge \\
\hline FC-46 & $\begin{array}{l}\text { Limited } \\
\text { investigative } \\
\text { power }\end{array}$ & $\begin{array}{l}\text { Limited } \\
\text { investigative } \\
\text { power }\end{array}$ & $\begin{array}{l}\text { In civil cases, there may be limited } \\
\text { investigative power given to investigators or } \\
\text { consulting firms to legally obtain data under } \\
\text { their respective jurisdictions. }\end{array}$ & $\begin{array}{l}\text { If this challenge were overcome, it } \\
\text { would improve the ability of } \\
\text { investigators to obtain forensic data } \\
\text { in varying jurisdictions. }\end{array}$ \\
\hline FC-47 & $\begin{array}{l}\text { Reliance on } \\
\text { cloud Providers }\end{array}$ & $\begin{array}{l}\text { Reliance on cloud } \\
\text { Providers }\end{array}$ & $\begin{array}{l}\text { Although data acquisition may frequently be } \\
\text { done without assistance from the cloud } \\
\text { Provider (e.g., with user credentials), it often } \\
\text { relies on the cooperation of cloud Providers, } \\
\text { typically in compliance with legal processes. } \\
\text { However, since cooperation may be limited by } \\
\text { the Provider's resources and number of } \\
\text { employees, an ever-increasing number of } \\
\text { cooperation requests becomes a problem. }\end{array}$ & $\begin{array}{l}\text { If this challenge were overcome, } \\
\text { cloud Providers would be better } \\
\text { equipped, in terms of physical and } \\
\text { human resources, to provide } \\
\text { assistance to forensic investigators in } \\
\text { forensic data collection. }\end{array}$ \\
\hline FC-48 & $\begin{array}{l}\text { Physical data } \\
\text { location }\end{array}$ & $\begin{array}{l}\text { Physical data } \\
\text { location }\end{array}$ & $\begin{array}{l}\text { Because physical locations of data are } \\
\text { unknown (due in part to lack of local storage } \\
\text { and access to the hardware), there are } \\
\text { difficulties in specifying and responding to } \\
\text { subpoenas. This can inhibit collection of } \\
\text { evidence by a first responder, particularly } \\
\text { dynamic evidence. Therefore, acquisition of } \\
\text { forensic images is preferred over seizure of } \\
\text { servers from a data center, which is not } \\
\text { feasible due to the conflict with privacy rights } \\
\text { of other tenants. }\end{array}$ & $\begin{array}{l}\text { If this challenge were overcome, } \\
\text { physical data locations would be } \\
\text { known, making it easier to specify } \\
\text { subpoenas and collect complete } \\
\text { evidence. }\end{array}$ \\
\hline
\end{tabular}




\begin{tabular}{|c|c|c|c|c|}
\hline FC ID & Short Title & Challenge & Description & Result of Overcoming Challenge \\
\hline FC-49 & Port protection & Port protection & $\begin{array}{l}\text { Because of the distributed nature of the cloud } \\
\text { computing environment, identifying and } \\
\text { accessing the ports to scan using SPAN or } \\
\text { TAP is a challenge. }\end{array}$ & $\begin{array}{l}\text { If this challenge were overcome, it } \\
\text { would be easier for a forensic } \\
\text { investigator to collect network traffic, } \\
\text { which could contain relevant forensic } \\
\text { evidence, in real time. }\end{array}$ \\
\hline FC-50 & $\begin{array}{l}\text { Transfer } \\
\text { protocol }\end{array}$ & Transfer protocol & $\begin{array}{l}\text { TCP/IP v6 dumps, Windows dumps, and TCP } \\
\text { segment deciphering are important forensic } \\
\text { tools that may be unavailable in some cloud } \\
\text { environments. }\end{array}$ & $\begin{array}{l}\text { If this challenge were overcome, it } \\
\text { would be easier for a forensic } \\
\text { investigator to have access to dumps } \\
\text { of TCP/IP network traffic, which } \\
\text { could contain relevant forensic } \\
\text { artifacts. }\end{array}$ \\
\hline FC-51 & e-discovery & e-discovery & $\begin{array}{l}\text { The location of data in cloud environments is } \\
\text { often uncertain. Therefore, completing e- } \\
\text { discovery requests within a reasonable } \\
\text { timeframe, as well as assuring that the requests } \\
\text { have been completed, is often a challenge. }\end{array}$ & $\begin{array}{l}\text { If this challenge were overcome, } \\
\text { completion of the e-discovery request } \\
\text { in a reasonable time frame would be } \\
\text { assured. }\end{array}$ \\
\hline
\end{tabular}




\begin{tabular}{|c|c|c|c|c|}
\hline FC ID & Short Title & Challenge & Description & Result of Overcoming Challenge \\
\hline FC-52 & $\begin{array}{l}\text { Lack of } \\
\text { international } \\
\text { agreements \& } \\
\text { laws }\end{array}$ & $\begin{array}{l}\text { Lack of } \\
\text { international } \\
\text { agreements and } \\
\text { laws }\end{array}$ & $\begin{array}{l}\text { There is a lack of international collaboration } \\
\text { and legislative mechanisms in cross-nation } \\
\text { data access and exchange. }\end{array}$ & $\begin{array}{l}\text { If this challenge were overcome, it } \\
\text { would be easier for the investigator } \\
\text { to access and exchange data across } \\
\text { international boundaries. }\end{array}$ \\
\hline FC-53 & $\begin{array}{l}\text { International } \\
\text { cloud services }\end{array}$ & $\begin{array}{l}\text { Lack of definition } \\
\text { of the scope for } \\
\text { acquiring data that } \\
\text { is stored on a } \\
\text { cloud service in a } \\
\text { different country } \\
\text { from that of the } \\
\text { investigator }\end{array}$ & $\begin{array}{l}\text { If the data is accessible, an investigator may } \\
\text { save a considerable amount of time by } \\
\text { acquiring the data from the connected service } \\
\text { rather than waiting for international requests. } \\
\text { However, authority on this matter is not } \\
\text { always clear. A lack of definition of the scope } \\
\text { of the acquisition of data in a foreign country } \\
\text { via remote connections depends on the laws } \\
\text { and regulations of the host country. } \\
\text { This challenge limits the investigator's ability } \\
\text { to begin a live analysis of the suspect system. } \\
\text { Requiring a formal international request to } \\
\text { access data from another country may result in } \\
\text { significant delays. }\end{array}$ & $\begin{array}{l}\text { If this challenge were overcome, it } \\
\text { would be easier and more } \\
\text { straightforward for investigators to } \\
\text { obtain live, real-time data on } \\
\text { international cloud services. }\end{array}$ \\
\hline
\end{tabular}




\begin{tabular}{|l|l|l|l|l|}
\hline FC ID & Short Title & \multicolumn{1}{|c|}{ Challenge } & \multicolumn{1}{|c|}{ Description } & Result of Overcoming Challenge \\
\hline FC-54 & Jurisdiction & Jurisdiction & $\begin{array}{l}\text { Many cloud systems operate in multiple } \\
\text { countries and regions, and each jurisdiction } \\
\text { has specific legal frameworks governing the } \\
\text { release, protection, and acceptable use of data. } \\
\text { While various international bodies have } \\
\text { attempted to adopt treaties for law } \\
\text { enforcement to collect and exchange forensic } \\
\text { data, there is no universal agreement between } \\
\text { countries that addresses jurisdictional issues } \\
\text { when cloud data is stored in multiple } \\
\text { countries. }\end{array}$ & $\begin{array}{l}\text { If this challenge were overcome, } \\
\text { there would be mechanisms in place } \\
\text { jhat provide agreements between } \\
\text { investigators and law enforcement } \\
\text { pertaining to their investigations. }\end{array}$ \\
\hline
\end{tabular}




\begin{tabular}{|c|c|c|c|c|}
\hline FC ID & Short Title & Challenge & Description & Result of Overcoming Challenge \\
\hline FC-55 & $\begin{array}{l}\text { International } \\
\text { communication }\end{array}$ & $\begin{array}{l}\text { International } \\
\text { communication }\end{array}$ & $\begin{array}{l}\text { Cloud computing blurs physical, policy, and } \\
\text { jurisdictional boundaries. However, law } \\
\text { enforcement at a global level has yet to find } \\
\text { effective, timely, and efficient international } \\
\text { communication and cooperation channels. } \\
\text { Conferences such as the International } \\
\text { Symposium on Cybercrime Response } \\
\text { specifically discuss international law } \\
\text { enforcement communication and collaboration } \\
\text { efforts. Global law enforcement } \\
\text { communication channels, such as } \\
\text { INTERPOL's I-24/7 network or the G8 } 24 / 7 \\
\text { network, connect many countries but are } \\
\text { limited by their structure and bureaucracy. } \\
\text { Many officers have found the global networks } \\
\text { to be somewhat effective if the request is not } \\
\text { overly urgent. However, these networks have } \\
\text { failed to address real-time requests for help } \\
\text { from countries under DDoS attack. Often, law } \\
\text { enforcement prefers faster, informal channels } \\
\text { to begin an international investigation rather } \\
\text { than traversing such networks. }\end{array}$ & $\begin{array}{l}\text { If this challenge were overcome, } \\
\text { investigators would achieve timely } \\
\text { and effective communication and } \\
\text { cooperation at an international level. }\end{array}$ \\
\hline FC-56 & $\begin{array}{l}\text { Confidentiality } \\
\text { and PII }\end{array}$ & $\begin{array}{l}\text { Concern for } \\
\text { confidentiality and } \\
\text { personally } \\
\text { identifiable } \\
\text { information (PII) }\end{array}$ & $\begin{array}{l}\text { Cloud computing has significant implications } \\
\text { for the privacy of personal information as well } \\
\text { as for the confidentiality of business and } \\
\text { governmental information. There is a lack of } \\
\text { legislative mechanisms facilitating evidence } \\
\text { retrieval involving confidential data. }\end{array}$ & $\begin{array}{l}\text { If this challenge were overcome, } \\
\text { access to confidential data pertaining } \\
\text { to investigations would be available } \\
\text { to investigators while also } \\
\text { maintaining the privacy and } \\
\text { confidentiality of all other tenants } \\
\text { and businesses. }\end{array}$ \\
\hline
\end{tabular}




\begin{tabular}{|c|c|c|c|c|}
\hline FC ID & Short Title & Challenge & Description & Result of Overcoming Challenge \\
\hline FC-58 ${ }^{10}$ & $\begin{array}{l}\text { Identifying } \\
\text { account owner }\end{array}$ & $\begin{array}{l}\text { Role management } \\
\text { makes it difficult } \\
\text { to identify suspect }\end{array}$ & $\begin{array}{l}\text { Insufficient granularity of user/process } \\
\text { identities and/or the lack of policy } \\
\text { enforcement requiring the use of unique } \\
\text { identities may inhibit the ability to positively } \\
\text { identify a subject. }\end{array}$ & $\begin{array}{l}\text { If this challenge were overcome, the } \\
\text { investigator could link all of an } \\
\text { individual's accounts and positively } \\
\text { identify the person as the owner of } \\
\text { the account. }\end{array}$ \\
\hline FC-59 & $\begin{array}{l}\text { Fictitious } \\
\text { identities }\end{array}$ & $\begin{array}{l}\text { Criminals can } \\
\text { create entire } \\
\text { fictitious identities } \\
\text { online to link to } \\
\text { their cloud } \\
\text { accounts, creating } \\
\text { excess noise' for } \\
\text { the forensic } \\
\text { investigator to } \\
\text { analyze }\end{array}$ & $\begin{array}{l}\text { Most cloud Providers will require a name, } \\
\text { address, and credit card to register an account. } \\
\text { A criminal can trivially obtain credit card } \\
\text { numbers and create fake profiles on existing } \\
\text { legitimate social media websites to make } \\
\text { his/her cloud identity appear to have a } \\
\text { corresponding equivalent in the real world. A } \\
\text { forensic investigator is then faced with the } \\
\text { daunting challenge of obtaining data on the } \\
\text { criminal identity from multiple online entities, } \\
\text { many of which are geographically spread } \\
\text { around the world. }\end{array}$ & $\begin{array}{l}\text { If this challenge were overcome, the } \\
\text { investigator could link all of the } \\
\text { accounts of an individual and } \\
\text { positively identify the real person - } \\
\text { the owner of the account. }\end{array}$ \\
\hline
\end{tabular}

${ }^{10}$ FC-10, FC-20, and FC-57 are deleted from the final document because the Working Group considered them to be obsolete challenges at the time of publication. Subsequent work derived from this document used the initial FC numbers, so the initial numbering system has been maintained for compatibility and traceability. 


\begin{tabular}{|c|c|c|c|c|}
\hline FC ID & Short Title & Challenge & Description & Result of Overcoming Challenge \\
\hline FC-60 & $\begin{array}{l}\text { Decoupling } \\
\text { user credentials } \\
\& \text { physical } \\
\text { location }\end{array}$ & $\begin{array}{l}\text { Decoupling } \\
\text { between cloud } \\
\text { user credentials } \\
\text { and physical users }\end{array}$ & $\begin{array}{l}\text { Due to the decoupling between cloud user } \\
\text { credentials and physical users, network-type } \\
\text { metadata plays a significant role in the data } \\
\text { acquisition process. A challenge is how to bind } \\
\text { a cloud username to a physical entity in order } \\
\text { to prove the physical ownership of the data } \\
\text { attributed to the cloud username. }\end{array}$ & $\begin{array}{l}\text { If the challenge were overcome, } \\
\text { coupling of the cloud username and } \\
\text { credentials to the physical person } \\
\text { using the account would be resolved. } \\
\text { In this way, the forensic investigator } \\
\text { could verify the physical person } \\
\text { using the username and the } \\
\text { credentials. }\end{array}$ \\
\hline FC-61 & $\begin{array}{l}\text { Authentication } \\
\text { and access } \\
\text { control }\end{array}$ & $\begin{array}{l}\text { Authentication and } \\
\text { access control }\end{array}$ & $\begin{array}{l}\text { Access control in cloud environments is } \\
\text { somewhat difficult and may not meet data } \\
\text { protection regulations. }\end{array}$ & $\begin{array}{l}\text { If this challenge were overcome, it } \\
\text { would be easier to implement data } \\
\text { protection regulations that allow } \\
\text { forensic investigators to determine } \\
\text { whether the account was used by } \\
\text { authorized or unauthorized entities. }\end{array}$ \\
\hline FC-62 & $\begin{array}{l}\text { Testability, } \\
\text { validation, and } \\
\text { scientific } \\
\text { principles not } \\
\text { standardized }\end{array}$ & $\begin{array}{l}\text { Testability, } \\
\text { validation, and } \\
\text { scientific } \\
\text { principles for } \\
\text { cloud forensics } \\
\text { tools have not } \\
\text { been standardized } \\
\text { across the industry }\end{array}$ & $\begin{array}{l}\text { While various countries and standards bodies } \\
\text { have attempted to create standards for } \\
\text { computer-based forensic tools, test and } \\
\text { validation processes for cloud forensic } \\
\text { hardware, software, policies, and techniques } \\
\text { have not been standardized. This lack of } \\
\text { standardization brings into question the } \\
\text { reliability and forensic soundness of the } \\
\text { evidence acquired by these tools. }\end{array}$ & $\begin{array}{l}\text { If this challenge were overcome, } \\
\text { there would be more forensic } \\
\text { techniques, tools, and methods } \\
\text { validated for accuracy and } \\
\text { repeatability. The result would be } \\
\text { accurate and repeatable forensic } \\
\text { methods that could be used by the } \\
\text { investigator. }\end{array}$ \\
\hline
\end{tabular}




\begin{tabular}{|c|c|c|c|c|}
\hline FC ID & Short Title & Challenge & Description & Result of Overcoming Challenge \\
\hline FC-63 & $\begin{array}{l}\text { Lack of } \\
\text { standard } \\
\text { processes \& } \\
\text { models }\end{array}$ & $\begin{array}{l}\text { Lack of standard } \\
\text { processes and } \\
\text { models }\end{array}$ & $\begin{array}{l}\text { There is no single process for digital forensics. } \\
\text { Although various process models have been } \\
\text { proposed, there is no single accepted standard, } \\
\text { and the majority of organizations are creating } \\
\text { their own SOPs, which may or may not be } \\
\text { based on an existing process model. }\end{array}$ & $\begin{array}{l}\text { If this challenge were overcome, } \\
\text { there would be more validated } \\
\text { standard procedures and best } \\
\text { practices, and it would be easier to } \\
\text { perform sound forensic investigations } \\
\text { that can be defended in courts. }\end{array}$ \\
\hline FC-64 & $\begin{array}{l}\text { Limited } \\
\text { knowledge of } \\
\text { logs and } \\
\text { records }\end{array}$ & $\begin{array}{l}\text { Custodians and } \\
\text { individuals } \\
\text { responsible for } \\
\text { record keeping in } \\
\text { cloud Provider } \\
\text { companies might } \\
\text { have limited } \\
\text { knowledge of } \\
\text { which logs and } \\
\text { records might be } \\
\text { sought after as } \\
\text { evidence }\end{array}$ & $\begin{array}{l}\text { Unlike a traditional computing environment to } \\
\text { which the forensic examiner might have access } \\
\text { to perform experiments, in the cloud, the } \\
\text { details of what logs are produced, what other } \\
\text { records are produced and/or kept, and where } \\
\text { they might be found are opaque except } \\
\text { through the testimony of representatives of the } \\
\text { Provider. In many cases, these individuals are } \\
\text { custodians of the records but do not have } \\
\text { detailed knowledge of technologies or actual } \\
\text { records that might be found if sought after. } \\
\text { Indeed, companies benefit from not keeping } \\
\text { such records or having custodians with only } \\
\text { limited knowledge. }\end{array}$ & $\begin{array}{l}\text { If this challenge were overcome, } \\
\text { custodians in cloud Provider } \\
\text { companies would have adequate } \\
\text { knowledge about forensically } \\
\text { meaningful data (logs and records) in } \\
\text { their cloud systems and the relevance } \\
\text { of such data to forensic } \\
\text { investigations, thus making it easier } \\
\text { to aggregate all forensic artifacts } \\
\text { pertaining to an investigation. }\end{array}$ \\
\hline
\end{tabular}




\begin{tabular}{|c|c|c|c|c|}
\hline FC ID & Short Title & Challenge & Description & Result of Overcoming Challenge \\
\hline FC-65 & $\begin{array}{l}\text { Cloud training } \\
\text { for } \\
\text { investigators }\end{array}$ & $\begin{array}{l}\text { Lack of training } \\
\text { materials that } \\
\text { educate } \\
\text { investigators on } \\
\text { cloud computing } \\
\text { technology and } \\
\text { cloud forensic } \\
\text { operating policies } \\
\text { and procedures }\end{array}$ & $\begin{array}{l}\text { Most digital forensic training materials are } \\
\text { outdated and not applicable to cloud } \\
\text { environments. The lack of knowledge about } \\
\text { cloud technology may interfere with remote } \\
\text { investigations where systems are not } \\
\text { physically accessible and where there is an } \\
\text { absence of proper tools to effectively } \\
\text { investigate the cloud computing environment. } \\
\text { Operating system virtualization permits the } \\
\text { implementation of many different operating } \\
\text { systems that share the same underlying } \\
\text { platform resources. This includes the sharing } \\
\text { of operating system and security software as } \\
\text { well as hardware. Moreover, few standard } \\
\text { operating policies are in place for cloud } \\
\text { forensics, which makes the nature of the } \\
\text { approach more trial and error than scientific. }\end{array}$ & $\begin{array}{l}\text { If the challenge were overcome, } \\
\text { forensic investigators would have } \\
\text { better training and the necessary } \\
\text { cloud training materials to make their } \\
\text { investigations easier and more sound. }\end{array}$ \\
\hline
\end{tabular}


Table 2: Categorization of cloud forensic challenges

Legend:

\begin{tabular}{|ll|c|}
\hline Cloud Essential Characteristics: & OD = On-demand self-service & Challenge/Functional-Capabilities Correlation: \\
& $\mathrm{BNA}=$ Broad network access & $\mathrm{S}=$ Specific \\
$\mathrm{RP}=$ Resource pooling & $\mathrm{Q}=$ Quasi \\
$\mathrm{RE}=$ Rapid elasticity & $\mathrm{G}=$ Generic \\
$\mathrm{MS}=$ Measured service & \\
\hline
\end{tabular}

\begin{tabular}{|c|c|c|c|c|c|c|}
\hline FC ID & Short Title & $\begin{array}{c}\text { Relevance of } \\
\text { Essential Cloud } \\
\text { Characteristics }\end{array}$ & $\begin{array}{c}\text { Labeling of Challenge/Functional- } \\
\text { Capabilities Correlation }\end{array}$ & $\begin{array}{c}\text { Primary } \\
\text { Category } \\
\text { (Subcategory) }\end{array}$ & $\begin{array}{c}\text { Related } \\
\text { Category } \\
\text { (Subcategory) }\end{array}$ & $\frac{\mathscr{e}}{\stackrel{0}{0}}$ \\
\hline FC-01 & $\begin{array}{l}\text { Deletion in the } \\
\text { cloud }\end{array}$ & $\mathrm{RP} / \mathrm{MS}$ & $\begin{array}{l}\text { S (specific to capabilities where stored } \\
\text { data needs to be both recovered and } \\
\text { attributed to a user; also deals with a } \\
\text { narrow aspect of forensics, namely } \\
\text { deletion and attribution) }\end{array}$ & Architecture & $\begin{array}{l}\text { Data } \\
\text { Collection } \\
\text { (Data } \\
\text { Recovery) }\end{array}$ & {$[23]$} \\
\hline FC-02 & $\begin{array}{l}\text { Recovering } \\
\text { overwritten data }\end{array}$ & $\mathrm{OD} / \mathrm{BNA} / \mathrm{RP} / \mathrm{RE}$ & $\begin{array}{l}\text { S (specific to capabilities where stored } \\
\text { data needs to be both recovered and } \\
\text { attributed to a user; also deals with a } \\
\text { narrow aspect of forensics, namely } \\
\text { deletion and attribution) }\end{array}$ & Architecture & $\begin{array}{l}\text { Data } \\
\text { Collection } \\
\text { (Data } \\
\text { Recovery) }\end{array}$ & $\begin{array}{l}{[24],} \\
{[4],} \\
{[25],} \\
{[26]}\end{array}$ \\
\hline FC-03 & $\begin{array}{l}\text { Evidence } \\
\text { correlation }\end{array}$ & $\mathrm{RE}$ & $\begin{array}{l}\mathrm{S} \text { (specific to when evidence } \\
\text { correlation across multiple Providers } \\
\text { is involved) }\end{array}$ & Analysis & N/A & $\begin{array}{l}{[24],} \\
{[4],} \\
{[27],} \\
{[28]}\end{array}$ \\
\hline
\end{tabular}




\begin{tabular}{|c|c|c|c|c|c|c|}
\hline FC ID & Short Title & $\begin{array}{c}\text { Relevance of } \\
\text { Essential Cloud } \\
\text { Characteristics }\end{array}$ & $\begin{array}{c}\text { Labeling of Challenge/Functional- } \\
\text { Capabilities Correlation }\end{array}$ & $\begin{array}{c}\text { Primary } \\
\text { Category } \\
\text { (Subcategory) }\end{array}$ & $\begin{array}{c}\text { Related } \\
\text { Category } \\
\text { (Subcategory) }\end{array}$ & 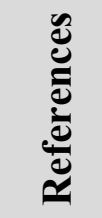 \\
\hline FC-04 & $\begin{array}{l}\text { Reconstructing } \\
\text { virtual storage }\end{array}$ & $\mathrm{OD} / \mathrm{RP} / \mathrm{RE}$ & $\begin{array}{l}\text { Q (can apply to many but not most or } \\
\text { all capabilities) }\end{array}$ & Analysis & $\begin{array}{l}\text { Incident First } \\
\text { Responders } \\
\text { (Reconstructio } \\
\text { n) }\end{array}$ & $\begin{array}{l}{[4],} \\
{[29],} \\
{[25]}\end{array}$ \\
\hline FC-05 & $\begin{array}{l}\text { Timestamp } \\
\text { synchronization }\end{array}$ & $\mathrm{RP} / \mathrm{RE} / \mathrm{MS}$ & $\begin{array}{l}\text { S (only applies when multiple time } \\
\text { sources are involved) }\end{array}$ & $\begin{array}{l}\text { Analysis } \\
\text { (Metadata } \\
\text { Logs) }\end{array}$ & N/A & $\begin{array}{l}{[24],} \\
{[4],} \\
{[30],} \\
{[31],} \\
{[32],} \\
{[33]}\end{array}$ \\
\hline FC-06 & $\begin{array}{l}\text { Log format } \\
\text { unification }\end{array}$ & $\mathrm{RP} / \mathrm{RE} / \mathrm{MS}$ & $\begin{array}{l}\text { Q (applies when logs are involved, } \\
\text { which is for many capabilities but not } \\
\text { all or most) }\end{array}$ & $\begin{array}{l}\text { Analysis } \\
\text { (Metadata } \\
\text { Logs) }\end{array}$ & N/A & $\begin{array}{l}{[24],} \\
{[4],} \\
{[31],} \\
{[28],} \\
{[34]}\end{array}$ \\
\hline
\end{tabular}




\begin{tabular}{|c|c|c|c|c|c|c|}
\hline FC ID & Short Title & $\begin{array}{l}\text { Relevance of } \\
\text { Essential Cloud } \\
\text { Characteristics }\end{array}$ & $\begin{array}{l}\text { Labeling of Challenge/Functional- } \\
\text { Capabilities Correlation }\end{array}$ & $\begin{array}{c}\text { Primary } \\
\text { Category } \\
\text { (Subcategory) }\end{array}$ & $\begin{array}{c}\text { Related } \\
\text { Category } \\
\text { (Subcategory) }\end{array}$ & 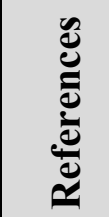 \\
\hline FC-07 & Use of metadata & $\begin{array}{l}\text { OD/BNA/RP/RE } \\
/ \mathrm{MS}\end{array}$ & $\begin{array}{l}\text { Q (applies only where metadata are } \\
\text { involved and the persistence thereof is } \\
\text { an issue) }\end{array}$ & $\begin{array}{l}\text { Analysis } \\
\text { (Metadata) }\end{array}$ & N/A & {$[27]$,} \\
\hline FC-08 & Log capture & $\begin{array}{l}\mathrm{OD} / \mathrm{BNA} / \mathrm{RP} / \mathrm{RE} \\
/ \mathrm{MS}\end{array}$ & $\begin{array}{l}\mathrm{S} \text { (only applies to network logs } \\
\text { involving dynamically assigned IP } \\
\text { addresses) }\end{array}$ & $\begin{array}{l}\text { Analysis } \\
\text { (Metadata) }\end{array}$ & N/A & $\begin{array}{l}{[24],} \\
{[4],} \\
{[34]}\end{array}$ \\
\hline FC-09 & $\begin{array}{l}\text { Interoperability } \\
\text { issues among } \\
\text { Providers }\end{array}$ & $R E$ & G (applies to most capabilities) & Architecture & $\begin{array}{l}\text { Standards } \\
\text { (Interoperabilit } \\
\text { y) }\end{array}$ & \begin{tabular}{|l}
{$[24]$,} \\
{$[4]$,} \\
{$[29]$,} \\
{$[36]$,} \\
{$[37]$,} \\
{$[38]$}
\end{tabular} \\
\hline
\end{tabular}




\begin{tabular}{|c|c|c|c|c|c|c|}
\hline FC ID & Short Title & $\begin{array}{l}\text { Relevance of } \\
\text { Essential Cloud } \\
\text { Characteristics }\end{array}$ & $\begin{array}{l}\text { Labeling of Challenge/Functional- } \\
\text { Capabilities Correlation }\end{array}$ & $\begin{array}{c}\text { Primary } \\
\text { Category } \\
\text { (Subcategory) }\end{array}$ & $\begin{array}{c}\text { Related } \\
\text { Category } \\
\text { (Subcategory) }\end{array}$ & 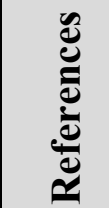 \\
\hline FC-11 & $\begin{array}{l}\text { No single source } \\
\text { for criminals }\end{array}$ & $\mathrm{OD} / \mathrm{BNA} / \mathrm{RP} / \mathrm{RE}$ & $\begin{array}{l}\text { S (only applies when multiple clouds } \\
\text { are involved) }\end{array}$ & Architecture & $\begin{array}{l}\text { Data } \\
\text { Collection }\end{array}$ & {$\left[\begin{array}{l}{[39],} \\
{[40]}\end{array}\right.$} \\
\hline FC-12 & $\begin{array}{l}\text { Detection of the } \\
\text { malicious act }\end{array}$ & $\mathrm{OD} / \mathrm{BNA} / \mathrm{RP} / \mathrm{RE}$ & $\begin{array}{l}\text { Q (applicability is limited to } \\
\text { capabilities that may be vulnerable to } \\
\text { steppingstone attacks) }\end{array}$ & Architecture & N/A & $\begin{array}{l}{[39],} \\
{[41],} \\
{[15]}\end{array}$ \\
\hline
\end{tabular}




\begin{tabular}{|c|c|c|c|c|c|c|}
\hline FC ID & Short Title & $\begin{array}{l}\text { Relevance of } \\
\text { Essential Cloud } \\
\text { Characteristics }\end{array}$ & $\begin{array}{l}\text { Labeling of Challenge/Functional- } \\
\text { Capabilities Correlation }\end{array}$ & $\begin{array}{c}\text { Primary } \\
\text { Category } \\
\text { (Subcategory) }\end{array}$ & $\begin{array}{c}\text { Related } \\
\text { Category } \\
\text { (Subcategory) }\end{array}$ & 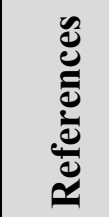 \\
\hline FC-13 & $\begin{array}{l}\text { Criminals access } \\
\text { to low cost } \\
\text { computing power }\end{array}$ & $\begin{array}{l}\mathrm{OD} / \mathrm{BNA} / \mathrm{RP} / \mathrm{RE} \\
/ \mathrm{MS}\end{array}$ & G & Architecture & N/A & {$\left[\begin{array}{l}{[39],} \\
{[42]}\end{array}\right.$} \\
\hline FC-14 & $\begin{array}{l}\text { Real-time } \\
\text { investigation } \\
\text { intelligence } \\
\text { processes not } \\
\text { possible }\end{array}$ & $\mathrm{OD} / \mathrm{BNA} / \mathrm{RP} / \mathrm{RE}$ & $\begin{array}{l}\text { S (only applies when real-time } \\
\text { forensics are employed) }\end{array}$ & Architecture & N/A & \begin{tabular}{|l}
{$[24]$,} \\
{$[4]$,} \\
{$[29]$,} \\
{$[31]$,} \\
{$[36]$,} \\
{$[43]$,} \\
{$[44]$}
\end{tabular} \\
\hline
\end{tabular}




\begin{tabular}{|c|c|c|c|c|c|c|}
\hline FC ID & Short Title & $\begin{array}{l}\text { Relevance of } \\
\text { Essential Cloud } \\
\text { Characteristics }\end{array}$ & $\begin{array}{l}\text { Labeling of Challenge/Functional- } \\
\text { Capabilities Correlation }\end{array}$ & $\begin{array}{c}\text { Primary } \\
\text { Category } \\
\text { (Subcategory) }\end{array}$ & $\begin{array}{c}\text { Related } \\
\text { Category } \\
\text { (Subcategory) }\end{array}$ & 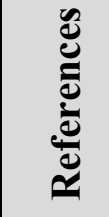 \\
\hline FC-15 & $\begin{array}{l}\text { Malicious code } \\
\text { may circumvent } \\
\text { VM isolation } \\
\text { methods }\end{array}$ & RP & $\begin{array}{l}\text { S (applies only to hypervisor or guest- } \\
\text { to-guest attacks) }\end{array}$ & Architecture & Anti-Forensics & \begin{tabular}{|l}
{$[4]$,} \\
{$[29]$,} \\
{$[45]$,} \\
{$[25]$,} \\
{$[26]$,} \\
{$[46]$}
\end{tabular} \\
\hline FC-16 & $\begin{array}{l}\text { Errors in cloud } \\
\text { management portal } \\
\text { configurations }\end{array}$ & $\mathrm{RP} / \mathrm{MS}$ & $\begin{array}{l}\text { S (applies only to hypervisor } \\
\text { management portal attacks) }\end{array}$ & $\begin{array}{l}\text { Architecture } \\
\text { (Multi- } \\
\text { Tenancy) }\end{array}$ & $\begin{array}{l}\text { Role } \\
\text { Management } \\
\text { (Identity } \\
\text { Management) }\end{array}$ & \\
\hline FC-17 & $\begin{array}{l}\text { Multiple venues } \\
\text { and geolocations }\end{array}$ & BNA/RP/RE/MS & $\begin{array}{l}\mathrm{G} \text { (forensics on most capabilities } \\
\text { involves clouds with multiple } \\
\text { geolocations) }\end{array}$ & Architecture & $\begin{array}{l}\text { Data } \\
\text { Collection }\end{array}$ & \begin{tabular}{|l}
{$[24]$,} \\
{$[4]$,} \\
{$[29]$,} \\
{$[30]$,} \\
{$[31]$,} \\
{$[36]$,} \\
{$[32]$,} \\
{$[47]$,} \\
{$[15]$}
\end{tabular} \\
\hline
\end{tabular}




\begin{tabular}{|c|c|c|c|c|c|c|}
\hline FC ID & Short Title & $\begin{array}{c}\text { Relevance of } \\
\text { Essential Cloud } \\
\text { Characteristics }\end{array}$ & $\begin{array}{l}\text { Labeling of Challenge/Functional- } \\
\text { Capabilities Correlation }\end{array}$ & $\begin{array}{c}\text { Primary } \\
\text { Category } \\
\text { (Subcategory) }\end{array}$ & $\begin{array}{c}\text { Related } \\
\text { Category } \\
\text { (Subcategory) }\end{array}$ & $\frac{\circlearrowright}{\stackrel{0}{0}}$ \\
\hline FC-18 & $\begin{array}{l}\text { Lack of } \\
\text { transparency }\end{array}$ & $\mathrm{OD} / \mathrm{RP} / \mathrm{RE} / \mathrm{MS}$ & G (applies to most capabilities) & Architecture & $\begin{array}{l}\text { Data } \\
\text { Collection }\end{array}$ & $\begin{array}{l}{[24],} \\
{[4],} \\
{[29],} \\
{[31],} \\
{[43],} \\
{[48],} \\
{[49]}\end{array}$ \\
\hline FC-19 & $\begin{array}{l}\text { Criminals can hide } \\
\text { in cloud }\end{array}$ & $\mathrm{OD} / \mathrm{BNA} / \mathrm{RP} / \mathrm{RE}$ & $\begin{array}{l}\text { G (applies the same way to most } \\
\text { capabilities regardless of the nature of } \\
\text { the capability; however, it only applies } \\
\text { when the attack is by a cell-based } \\
\text { criminal organization) }\end{array}$ & Architecture & $\begin{array}{l}\text { Legal } \\
\text { (Contract / } \\
\text { SLA) } \\
\text { Role } \\
\text { Management } \\
\text { (Identity } \\
\text { Management) }\end{array}$ & [39] \\
\hline FC-21 & $\begin{array}{l}\text { Potential evidence } \\
\text { segregation }\end{array}$ & $\mathrm{OD} / \mathrm{RP} / \mathrm{RE}$ & $\begin{array}{l}\text { G (applies the same way to most } \\
\text { capabilities regardless of the nature of } \\
\text { the capability) }\end{array}$ & $\begin{array}{l}\text { Architecture } \\
\text { (Data } \\
\text { Segregation) } \\
\text { (Multi- } \\
\text { Tenancy) }\end{array}$ & $\begin{array}{l}\text { Data } \\
\text { Collection }\end{array}$ & $\begin{array}{l}{[24],} \\
{[4],} \\
{[29],} \\
{[36],} \\
{[43],} \\
{[50],} \\
{[51]}\end{array}$ \\
\hline
\end{tabular}




\begin{tabular}{|c|c|c|c|c|c|c|}
\hline FC ID & Short Title & \begin{tabular}{|c|} 
Relevance of \\
Essential Cloud \\
Characteristics
\end{tabular} & $\begin{array}{l}\text { Labeling of Challenge/Functional- } \\
\text { Capabilities Correlation }\end{array}$ & $\begin{array}{c}\text { Primary } \\
\text { Category } \\
\text { (Subcategory) }\end{array}$ & $\begin{array}{c}\text { Related } \\
\text { Category } \\
\text { (Subcategory) }\end{array}$ & 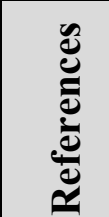 \\
\hline FC-22 & Boundaries & OD/BNA/RP/RE & $\begin{array}{l}\mathrm{G} \text { (applies the same way to most } \\
\text { capabilities regardless of the nature of } \\
\text { the capability) }\end{array}$ & $\begin{array}{l}\text { Architecture } \\
\text { (Multi- } \\
\text { Tenancy) }\end{array}$ & $\begin{array}{l}\text { Data } \\
\text { Collection }\end{array}$ & {$[48]$} \\
\hline FC-23 & Secure provenance & OD/BNA/RP/RE & $\begin{array}{l}\text { G (applies the same way to most } \\
\text { capabilities regardless of the nature of } \\
\text { the capability) }\end{array}$ & $\begin{array}{l}\text { Architecture } \\
\text { (Provenance) }\end{array}$ & N/A & {$[23]$} \\
\hline FC-24 & $\begin{array}{l}\text { Data chain of } \\
\text { custody }\end{array}$ & $\begin{array}{l}\mathrm{OD} / \mathrm{BNA} / \mathrm{RP} / \mathrm{RE} \\
/ \mathrm{MS}\end{array}$ & $\begin{array}{l}\mathrm{G} \text { (applies the same way to most } \\
\text { capabilities regardless of the nature of } \\
\text { the capability) }\end{array}$ & $\begin{array}{l}\text { Architecture } \\
\text { (Provenance) }\end{array}$ & N/A & \begin{tabular}{|l}
{$[24]$,} \\
{$[4]$,} \\
{$[29]$,} \\
{$[31]$,} \\
{$[36]$,} \\
{$[32]$,} \\
{$[52]$,} \\
{$[43]$}
\end{tabular} \\
\hline
\end{tabular}




\begin{tabular}{|c|c|c|c|c|c|c|}
\hline FC ID & Short Title & $\begin{array}{c}\text { Relevance of } \\
\text { Essential Cloud } \\
\text { Characteristics }\end{array}$ & $\begin{array}{l}\text { Labeling of Challenge/Functional- } \\
\text { Capabilities Correlation }\end{array}$ & $\begin{array}{c}\text { Primary } \\
\text { Category } \\
\text { (Subcategory) }\end{array}$ & $\begin{array}{c}\text { Related } \\
\text { Category } \\
\text { (Subcategory) }\end{array}$ & 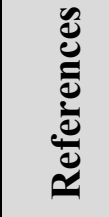 \\
\hline FC-25 & $\begin{array}{l}\text { Decreased access } \\
\text { and data control }\end{array}$ & $\begin{array}{l}\mathrm{OD} / \mathrm{BNA} / \mathrm{RP} / \mathrm{RE} \\
/ \mathrm{MS}\end{array}$ & G (applies to most capabilities) & $\begin{array}{l}\text { Data } \\
\text { Collection }\end{array}$ & N/A & $\begin{array}{l}{[24],} \\
{[4],} \\
{[31],} \\
{[50],} \\
{[53]}\end{array}$ \\
\hline FC-26 & $\begin{array}{l}\text { Chain of } \\
\text { dependencies }\end{array}$ & $\begin{array}{l}\text { OD/BNA/RP/RE } \\
\text { /MS }\end{array}$ & $\begin{array}{l}\text { Q (applies only to capabilities that } \\
\text { could be spread across multiple } \\
\text { Providers, usually involving } \\
\text { applications [e.g., Netflix or } \\
\text { Facebook]) }\end{array}$ & $\begin{array}{l}\text { Data } \\
\text { Collection }\end{array}$ & N/A & \begin{tabular}{|l}
{$[24]$,} \\
{$[4]$,} \\
{$[31]$}
\end{tabular} \\
\hline
\end{tabular}




\begin{tabular}{|c|c|c|c|c|c|c|}
\hline FC ID & Short Title & $\begin{array}{l}\text { Relevance of } \\
\text { Essential Cloud } \\
\text { Characteristics }\end{array}$ & $\begin{array}{l}\text { Labeling of Challenge/Functional- } \\
\text { Capabilities Correlation }\end{array}$ & $\begin{array}{c}\text { Primary } \\
\text { Category } \\
\text { (Subcategory) }\end{array}$ & $\begin{array}{c}\text { Related } \\
\text { Category } \\
\text { (Subcategory) }\end{array}$ & 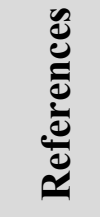 \\
\hline FC-27 & Locating evidence & $\begin{array}{l}\mathrm{OD} / \mathrm{BNA} / \mathrm{RE} / \mathrm{RP} \\
\text { /MS }\end{array}$ & S (deals with e-discovery) & $\begin{array}{l}\text { Data } \\
\text { Collection }\end{array}$ & N/A & $\begin{array}{l}{[24],} \\
{[4],} \\
{[29],} \\
{[31],} \\
{[32],} \\
{[54],} \\
{[27],} \\
{[48],} \\
{[44],} \\
{[55]}\end{array}$ \\
\hline FC-28 & Data location & $\mathrm{OD} / \mathrm{RP} / \mathrm{RE} / \mathrm{MS}$ & $\begin{array}{l}\mathrm{G} \text { (applies in much the same way } \\
\text { regardless of the nature of the } \\
\text { capability being investigated) }\end{array}$ & $\begin{array}{l}\text { Data } \\
\text { Collection }\end{array}$ & N/A & $\begin{array}{l}{[24],} \\
{[4],} \\
{[29],} \\
{[30],} \\
{[31],} \\
{[32],} \\
{[47],} \\
{[45],} \\
{[54],} \\
{[52],} \\
{[27],} \\
{[25],} \\
{[55],}\end{array}$ \\
\hline
\end{tabular}




\begin{tabular}{|c|c|c|c|c|c|c|}
\hline FC ID & Short Title & \begin{tabular}{|c|} 
Relevance of \\
Essential Cloud \\
Characteristics
\end{tabular} & $\begin{array}{c}\text { Labeling of Challenge/Functional- } \\
\text { Capabilities Correlation }\end{array}$ & $\begin{array}{c}\text { Primary } \\
\text { Category } \\
\text { (Subcategory) }\end{array}$ & $\begin{array}{c}\text { Related } \\
\text { Category } \\
\text { (Subcategory) }\end{array}$ & 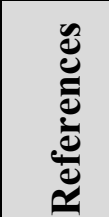 \\
\hline FC-29 & $\begin{array}{l}\text { Imaging, isolating, } \\
\text { and collecting data }\end{array}$ & $\begin{array}{l}\mathrm{OD} / \mathrm{BNA} / \mathrm{RP} / \mathrm{RE} \\
/ \mathrm{MS}\end{array}$ & $\begin{array}{l}\mathrm{G} \text { (deals with any data in files and } \\
\text { databases when system incorporates } \\
\text { mirroring) }\end{array}$ & $\begin{array}{l}\text { Data } \\
\text { Collection }\end{array}$ & N/A & \begin{tabular}{|l}
{$[24]$,} \\
{$[4]$,} \\
{$[56]$}
\end{tabular} \\
\hline FC-30 & $\begin{array}{l}\text { Data available for } \\
\text { a limited time }\end{array}$ & $\begin{array}{l}\mathrm{OD} / \mathrm{BNA} / \mathrm{RP} / \mathrm{RE} \\
/ \mathrm{MS}\end{array}$ & $\begin{array}{l}\text { S (deals specifically with deallocated } \\
\text { VMs and recovery of information } \\
\text { from them) }\end{array}$ & $\begin{array}{l}\text { Data } \\
\text { Collection }\end{array}$ & N/A & $\begin{array}{l}{[25],} \\
{[57],} \\
{[6]}\end{array}$ \\
\hline FC-31 & $\begin{array}{l}\text { Locating storage } \\
\text { media }\end{array}$ & $\begin{array}{l}\mathrm{OD} / \mathrm{BNA} / \mathrm{RP} / \mathrm{RE} \\
/ \mathrm{MS}\end{array}$ & $\begin{array}{l}\mathrm{Q} \text { (deals with remote storage media, } \\
\text { which applies to many capabilities) }\end{array}$ & $\begin{array}{l}\text { Data } \\
\text { Collection }\end{array}$ & N/A & \begin{tabular}{|l}
{$[24]$,} \\
{$[4]$,} \\
{$[29]$,} \\
{$[32]$,} \\
{$[47]$,} \\
{$[54]$,} \\
{$[52]$,} \\
{$[27]$,} \\
{$[25]$}
\end{tabular} \\
\hline
\end{tabular}




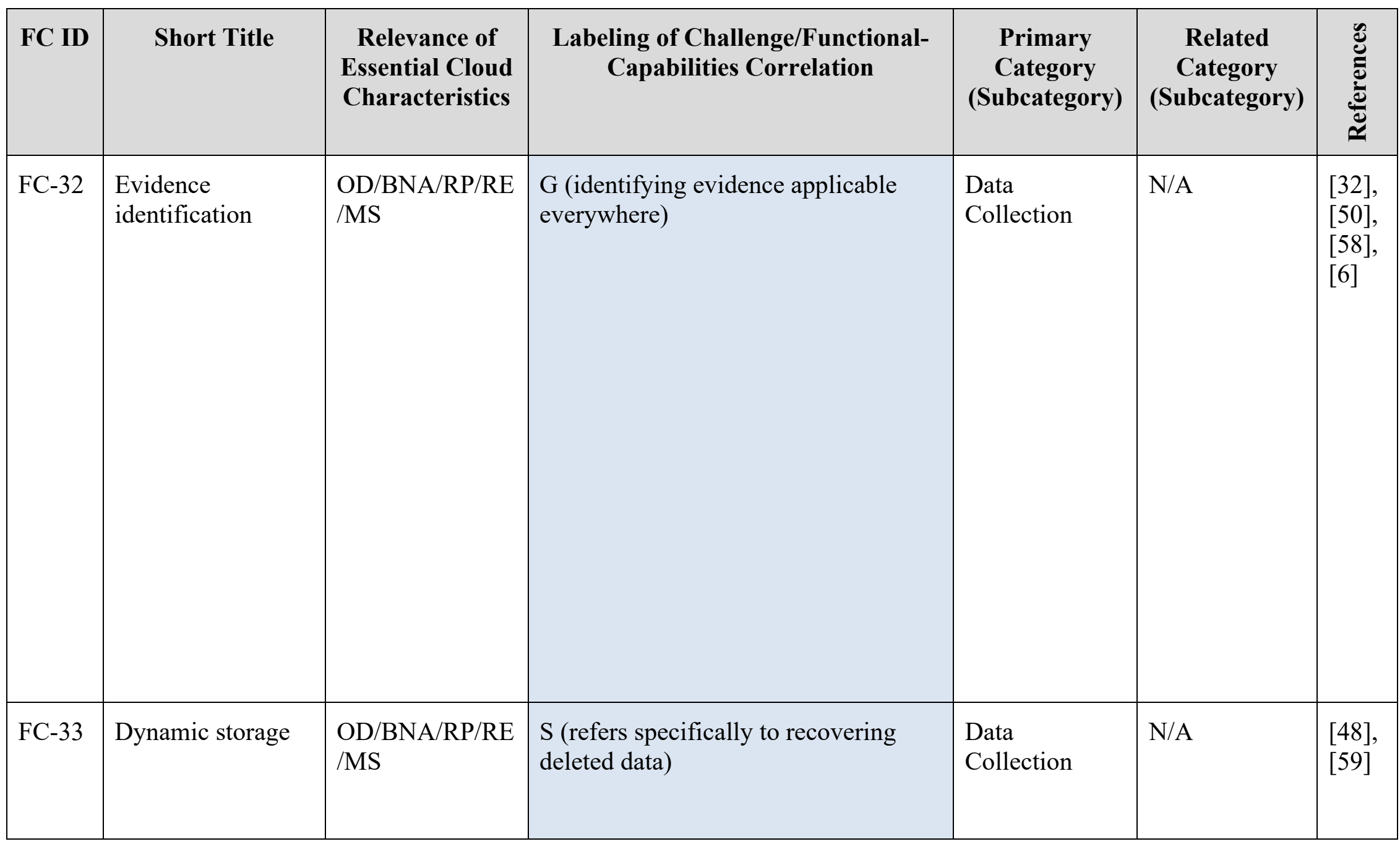




\begin{tabular}{|c|c|c|c|c|c|c|}
\hline FC ID & Short Title & $\begin{array}{c}\text { Relevance of } \\
\text { Essential Cloud } \\
\text { Characteristics }\end{array}$ & $\begin{array}{c}\text { Labeling of Challenge/Functional- } \\
\text { Capabilities Correlation }\end{array}$ & $\begin{array}{c}\text { Primary } \\
\text { Category } \\
\text { (Subcategory) }\end{array}$ & $\begin{array}{c}\text { Related } \\
\text { Category } \\
\text { (Subcategory) }\end{array}$ & 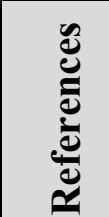 \\
\hline FC-34 & Live forensics & $\begin{array}{l}\mathrm{OD} / \mathrm{BNA} / \mathrm{RP} / \mathrm{RE} \\
\text { /MS }\end{array}$ & $\begin{array}{l}\mathrm{S} \text { (deals specifically with volatile data } \\
\text { and live forensics) }\end{array}$ & $\begin{array}{l}\text { Data } \\
\text { Collection }\end{array}$ & Architecture & \begin{tabular}{|l}
{$[24]$,} \\
{$[4]$,} \\
{$[29]$,} \\
{$[31]$,} \\
{$[36]$,} \\
{$[43]$,} \\
{$[44]$,} \\
{$[60]$}
\end{tabular} \\
\hline
\end{tabular}




\begin{tabular}{|c|c|c|c|c|c|c|}
\hline FC ID & Short Title & $\begin{array}{l}\text { Relevance of } \\
\text { Essential Cloud } \\
\text { Characteristics }\end{array}$ & $\begin{array}{l}\text { Labeling of Challenge/Functional- } \\
\text { Capabilities Correlation }\end{array}$ & $\begin{array}{c}\text { Primary } \\
\text { Category } \\
\text { (Subcategory) }\end{array}$ & $\begin{array}{c}\text { Related } \\
\text { Category } \\
\text { (Subcategory) }\end{array}$ & 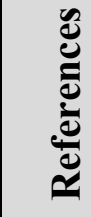 \\
\hline FC-35 & $\begin{array}{l}\text { Resource } \\
\text { abstraction }\end{array}$ & $\begin{array}{l}\mathrm{OD} / \mathrm{BNA} / \mathrm{RP} / \mathrm{RE} \\
/ \mathrm{MS}\end{array}$ & $\begin{array}{l}\mathrm{G} \text { (the need to know information } \\
\text { about the cloud system to do forensics } \\
\text { applies generically) }\end{array}$ & $\begin{array}{l}\text { Data } \\
\text { Collection }\end{array}$ & Architecture & $\begin{array}{l}{[49]} \\
{[6]}\end{array}$ \\
\hline FC-36 & $\begin{array}{l}\text { Application details } \\
\text { are unavailable }\end{array}$ & MS & S (limited to applications) & $\begin{array}{l}\text { Data } \\
\text { Collection }\end{array}$ & Architecture & [32] \\
\hline FC-37 & $\begin{array}{l}\text { Additional } \\
\text { evidence } \\
\text { collection }\end{array}$ & $\mathrm{OD} / \mathrm{RP} / \mathrm{RE} / \mathrm{MS}$ & $\mathrm{G}$ (also same issue in non-cloud) & $\begin{array}{l}\text { Data } \\
\text { Collection }\end{array}$ & Architecture & $\begin{array}{l}{[32]} \\
{[49]}\end{array}$ \\
\hline
\end{tabular}




\begin{tabular}{|c|c|c|c|c|c|c|}
\hline FC ID & Short Title & $\begin{array}{l}\text { Relevance of } \\
\text { Essential Cloud } \\
\text { Characteristics }\end{array}$ & $\begin{array}{l}\text { Labeling of Challenge/Functional- } \\
\text { Capabilities Correlation }\end{array}$ & $\begin{array}{c}\text { Primary } \\
\text { Category } \\
\text { (Subcategory) }\end{array}$ & $\begin{array}{c}\text { Related } \\
\text { Category } \\
\text { (Subcategory) }\end{array}$ & 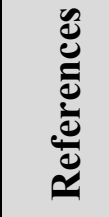 \\
\hline FC-38 & Imaging the cloud & $\begin{array}{l}\mathrm{OD} / \mathrm{BNA} / \mathrm{RP} / \mathrm{RE} \\
/ \mathrm{MS}\end{array}$ & $\begin{array}{l}\text { Q (applies to imaging, which is not } \\
\text { general but can be more broad than } \\
\text { specific) }\end{array}$ & $\begin{array}{l}\text { Data } \\
\text { Collection }\end{array}$ & Architecture & \begin{tabular}{|l}
{$[24]$,} \\
{$[4]$,} \\
{$[30]$,} \\
{$[45]$,} \\
{$[25]$,} \\
{$[50]$,} \\
{$[60]$}
\end{tabular} \\
\hline FC-39 & $\begin{array}{l}\text { Selective data } \\
\text { acquisition }\end{array}$ & $\begin{array}{l}\mathrm{OD} / \mathrm{BNA} / \mathrm{RP} / \mathrm{RE} \\
/ \mathrm{MS}\end{array}$ & $\begin{array}{l}\text { G (could apply to almost any } \\
\text { capability) }\end{array}$ & $\begin{array}{l}\text { Data } \\
\text { Collection }\end{array}$ & $\begin{array}{l}\text { Incident First } \\
\text { Responders }\end{array}$ & {$[61]$,} \\
\hline FC-40 & $\begin{array}{l}\text { Cryptographic key } \\
\text { management }\end{array}$ & $\begin{array}{l}\mathrm{OD} / \mathrm{BNA} / \mathrm{RP} / \mathrm{RE} \\
/ \mathrm{MS}\end{array}$ & S & $\begin{array}{l}\text { Data } \\
\text { Collection }\end{array}$ & $\begin{array}{l}\text { Legal } \\
\text { (Privacy) }\end{array}$ & \begin{tabular}{|l}
{$[24]$,} \\
{$[4]$,} \\
{$[29]$,} \\
{$[31]$,} \\
{$[43]$,} \\
{$[63]$}
\end{tabular} \\
\hline FC-41 & $\begin{array}{l}\text { Ambiguous trust } \\
\text { boundaries }\end{array}$ & $\begin{array}{l}\text { OD/BNA/RP/RE } \\
\text { /MS }\end{array}$ & $\begin{array}{l}\text { G (many ways that boundary of trust } \\
\text { can be ambiguous) }\end{array}$ & $\begin{array}{l}\text { Data } \\
\text { Collection } \\
\text { (Data } \\
\text { Integrity) }\end{array}$ & N/A & $\begin{array}{l}{[25],} \\
{[64],} \\
{[60]}\end{array}$ \\
\hline
\end{tabular}




\begin{tabular}{|c|c|c|c|c|c|c|}
\hline FC ID & Short Title & $\begin{array}{l}\text { Relevance of } \\
\text { Essential Cloud } \\
\text { Characteristics }\end{array}$ & $\begin{array}{l}\text { Labeling of Challenge/Functional- } \\
\text { Capabilities Correlation }\end{array}$ & $\begin{array}{c}\text { Primary } \\
\text { Category } \\
\text { (Subcategory) }\end{array}$ & $\begin{array}{c}\text { Related } \\
\text { Category } \\
\text { (Subcategory) }\end{array}$ & 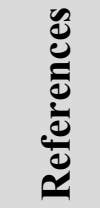 \\
\hline FC-42 & $\begin{array}{l}\text { Data integrity and } \\
\text { evidence } \\
\text { preservation }\end{array}$ & $\begin{array}{l}\mathrm{OD} / \mathrm{BNA} / \mathrm{RP} / \mathrm{RE} \\
\text { /MS }\end{array}$ & $\begin{array}{l}\text { G (this can apply to nearly any } \\
\text { capability with very few exceptions) }\end{array}$ & $\begin{array}{l}\text { Data } \\
\text { Collection } \\
\text { (Data } \\
\text { Integrity) }\end{array}$ & Architecture & $\begin{array}{l}{[32],} \\
{[11]}\end{array}$ \\
\hline FC-43 & Root of trust & $\begin{array}{l}\mathrm{OD} / \mathrm{BNA} / \mathrm{RP} / \mathrm{RE} \\
\text { /MS }\end{array}$ & $\begin{array}{l}\mathrm{Q} \text { (only applies to capabilities that are } \\
\text { affected by this abstraction) }\end{array}$ & $\begin{array}{l}\text { Data } \\
\text { Collection } \\
\text { (Data } \\
\text { Integrity) }\end{array}$ & Legal & $\begin{array}{l}{[62],} \\
{[48],} \\
{[64],} \\
{[60]}\end{array}$ \\
\hline
\end{tabular}




\begin{tabular}{|c|c|c|c|c|c|c|}
\hline FC ID & Short Title & $\begin{array}{l}\text { Relevance of } \\
\text { Essential Cloud } \\
\text { Characteristics }\end{array}$ & $\begin{array}{l}\text { Labeling of Challenge/Functional- } \\
\text { Capabilities Correlation }\end{array}$ & $\begin{array}{c}\text { Primary } \\
\text { Category } \\
\text { (Subcategory) }\end{array}$ & $\begin{array}{c}\text { Related } \\
\text { Category } \\
\text { (Subcategory) }\end{array}$ & 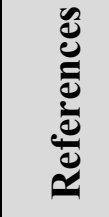 \\
\hline FC-44 & $\begin{array}{l}\text { Competence and } \\
\text { trustworthiness }\end{array}$ & OD/BNA/RE & $\begin{array}{l}\text { G (could apply to almost any } \\
\text { capability) }\end{array}$ & $\begin{array}{l}\text { Incident First } \\
\text { Responders }\end{array}$ & $\begin{array}{l}\text { Legal } \\
\text { (Contract / } \\
\text { SLA) }\end{array}$ & \begin{tabular}{|l}
{$[62]$,} \\
{$[48]$,} \\
{$[64]$,} \\
{$[65]$,} \\
{$[50]$,} \\
{$[60]$}
\end{tabular} \\
\hline FC-45 & $\begin{array}{l}\text { Missing terms in } \\
\text { contract or SLA }\end{array}$ & $\begin{array}{l}\mathrm{OD} / \mathrm{BNA} / \mathrm{RP} / \mathrm{RE} \\
/ \mathrm{MS}\end{array}$ & $\begin{array}{l}\text { Q (applicable only to capabilities } \\
\text { where forensic data can be provided } \\
\text { by Provider) }\end{array}$ & $\begin{array}{l}\text { Legal } \\
\text { (Contract / } \\
\text { SLA) }\end{array}$ & N/A & \begin{tabular}{|l}
{$[24]$,} \\
{$[4]$,} \\
{$[31]$,} \\
{$[66]$}
\end{tabular} \\
\hline FC-46 & $\begin{array}{l}\text { Limited } \\
\text { investigative } \\
\text { power }\end{array}$ & OD/BNA/RP/RE & $\begin{array}{l}\text { Q (only applicable where jurisdiction } \\
\text { is an issue; when it is an issue, this is } \\
\text { generic) }\end{array}$ & Legal & N/A & \begin{tabular}{|l}
{$[24]$,} \\
{$[4]$,} \\
{$[54]$,} \\
{$[55]$}
\end{tabular} \\
\hline FC-47 & $\begin{array}{l}\text { Reliance on cloud } \\
\text { Providers }\end{array}$ & $\mathrm{RP} / \mathrm{RE} / \mathrm{MS}$ & $\begin{array}{l}\text { G (could apply to almost any } \\
\text { capability) }\end{array}$ & Legal & N/A & \begin{tabular}{|l}
{$[24]$,} \\
{$[4]$,} \\
{$[29]$,} \\
{$[30]$,} \\
{$[54]$,} \\
{$[52]$,} \\
{$[62]$,} \\
{$[53]$}
\end{tabular} \\
\hline
\end{tabular}




\begin{tabular}{|c|c|c|c|c|c|c|}
\hline FC ID & Short Title & $\begin{array}{l}\text { Relevance of } \\
\text { Essential Cloud } \\
\text { Characteristics }\end{array}$ & $\begin{array}{l}\text { Labeling of Challenge/Functional- } \\
\text { Capabilities Correlation }\end{array}$ & $\begin{array}{c}\text { Primary } \\
\text { Category } \\
\text { (Subcategory) }\end{array}$ & $\begin{array}{c}\text { Related } \\
\text { Category } \\
\text { (Subcategory) }\end{array}$ & 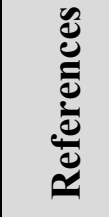 \\
\hline FC-48 & $\begin{array}{l}\text { Physical data } \\
\text { location }\end{array}$ & $\mathrm{RE}$ & $\begin{array}{l}\mathrm{S} \text { (only applies where physical } \\
\text { location is relevant and subpoenas are } \\
\text { involved) }\end{array}$ & Legal & N/A & \begin{tabular}{|l}
{$[24]$,} \\
{$[4]$,} \\
{$[29]$,} \\
{$[31]$,} \\
{$[47]$}
\end{tabular} \\
\hline FC-49 & Port protection & BNA/RP/RE/MS & S (very specific) & Legal & $\begin{array}{l}\text { Data } \\
\text { Collection }\end{array}$ & \\
\hline
\end{tabular}




\begin{tabular}{|c|c|c|c|c|c|c|}
\hline FC ID & Short Title & $\begin{array}{l}\text { Relevance of } \\
\text { Essential Cloud } \\
\text { Characteristics }\end{array}$ & $\begin{array}{c}\text { Labeling of Challenge/Functional- } \\
\text { Capabilities Correlation }\end{array}$ & $\begin{array}{c}\text { Primary } \\
\text { Category } \\
\text { (Subcategory) }\end{array}$ & $\begin{array}{c}\text { Related } \\
\text { Category } \\
\text { (Subcategory) }\end{array}$ & 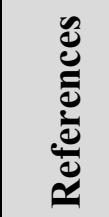 \\
\hline FC-50 & Transfer protocol & BNA/MS & $\mathrm{S}$ (same as FC49) & Legal & $\begin{array}{l}\text { Data } \\
\text { Collection }\end{array}$ & \\
\hline FC-51 & e-discovery & $\begin{array}{l}\text { OD/BNA/RP/RE } \\
\text { /MS }\end{array}$ & S (applies to e-discovery only) & Legal & $\begin{array}{l}\text { Data } \\
\text { Collection }\end{array}$ & \begin{tabular}{|l}
{$[24]$,} \\
{$[4]$,} \\
{$[27]$,} \\
{$[55]$}
\end{tabular} \\
\hline FC-52 & $\begin{array}{l}\text { Lack of } \\
\text { international } \\
\text { agreements \& laws }\end{array}$ & $\begin{array}{l}\mathrm{OD} / \mathrm{BNA} / \mathrm{RP} / \mathrm{RE} \\
\text { /MS }\end{array}$ & $\begin{array}{l}\text { Q (applicable only when international } \\
\text { boundaries are an issue but generic } \\
\text { otherwise) }\end{array}$ & $\begin{array}{l}\text { Legal } \\
\text { (Jurisdiction) }\end{array}$ & N/A & $\begin{array}{l}{[24],} \\
{[4],} \\
{[36],} \\
{[52],} \\
{[67]}\end{array}$ \\
\hline FC-53 & $\begin{array}{l}\text { International cloud } \\
\text { services }\end{array}$ & BNA/RP/RE/MS & $\begin{array}{l}\text { S (only applies for live, real-time data } \\
\text { across international boundaries) }\end{array}$ & $\begin{array}{l}\text { Legal } \\
\text { (Jurisdiction) }\end{array}$ & N/A & [62] \\
\hline
\end{tabular}




\begin{tabular}{|c|c|c|c|c|c|c|}
\hline FC ID & Short Title & $\begin{array}{l}\text { Relevance of } \\
\text { Essential Cloud } \\
\text { Characteristics }\end{array}$ & $\begin{array}{l}\text { Labeling of Challenge/Functional- } \\
\text { Capabilities Correlation }\end{array}$ & $\begin{array}{c}\text { Primary } \\
\text { Category } \\
\text { (Subcategory) }\end{array}$ & $\begin{array}{c}\text { Related } \\
\text { Category } \\
\text { (Subcategory) }\end{array}$ & 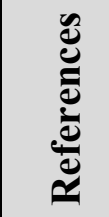 \\
\hline FC-54 & Jurisdiction & RP & $\begin{array}{l}\mathrm{Q} \text { (only applies when jurisdiction is an } \\
\text { issue, and then it is generic) }\end{array}$ & $\begin{array}{l}\text { Legal } \\
\text { (Jurisdiction) }\end{array}$ & N/A & \begin{tabular}{|l}
{$[24]$,} \\
{$[4]$,} \\
{$[29]$,} \\
{$[30]$,} \\
{$[31]$,} \\
{$[36]$,} \\
{$[32]$,}
\end{tabular} \\
\hline
\end{tabular}




\begin{tabular}{|c|c|c|c|c|c|c|}
\hline FC ID & Short Title & $\begin{array}{l}\text { Relevance of } \\
\text { Essential Cloud } \\
\text { Characteristics }\end{array}$ & $\begin{array}{c}\text { Labeling of Challenge/Functional- } \\
\text { Capabilities Correlation }\end{array}$ & $\begin{array}{c}\text { Primary } \\
\text { Category } \\
\text { (Subcategory) }\end{array}$ & $\begin{array}{c}\text { Related } \\
\text { Category } \\
\text { (Subcategory) }\end{array}$ & 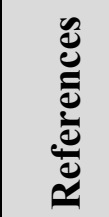 \\
\hline FC-55 & $\begin{array}{l}\text { International } \\
\text { communication }\end{array}$ & $\begin{array}{l}\mathrm{OD} / \mathrm{BNA} / \mathrm{RP} / \mathrm{RE} \\
/ \mathrm{MS}\end{array}$ & $\begin{array}{l}\text { Q (applicable only when international } \\
\text { boundaries are an issue but generic } \\
\text { otherwise) }\end{array}$ & $\begin{array}{l}\text { Legal } \\
\text { (Jurisdiction) }\end{array}$ & N/A & \begin{tabular}{|l}
{$[24]$,} \\
{$[4]$,} \\
{$[29]$,} \\
{$[31]$,} \\
{$[32]$,} \\
{$[47]$,} \\
{$[52]$,} \\
{$[61]$,} \\
{$[69]$}
\end{tabular} \\
\hline FC-56 & $\begin{array}{l}\text { Confidentiality } \\
\text { and PII }\end{array}$ & RP/MS & $\begin{array}{l}\text { S (limited to PII, confidential, or } \\
\text { sensitive data) }\end{array}$ & $\begin{array}{l}\text { Legal } \\
\text { (Privacy) }\end{array}$ & N/A & {$\left[\begin{array}{l}{[36],} \\
{[52],} \\
{[70]}\end{array}\right.$} \\
\hline
\end{tabular}




\begin{tabular}{|c|c|c|c|c|c|c|}
\hline FC ID & Short Title & $\begin{array}{l}\text { Relevance of } \\
\text { Essential Cloud } \\
\text { Characteristics }\end{array}$ & $\begin{array}{l}\text { Labeling of Challenge/Functional- } \\
\text { Capabilities Correlation }\end{array}$ & $\begin{array}{c}\text { Primary } \\
\text { Category } \\
\text { (Subcategory) }\end{array}$ & $\begin{array}{c}\text { Related } \\
\text { Category } \\
\text { (Subcategory) }\end{array}$ & 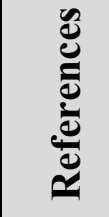 \\
\hline FC-58 & $\begin{array}{l}\text { Identifying } \\
\text { account owner }\end{array}$ & $\begin{array}{l}\mathrm{OD} / \mathrm{BNA} / \mathrm{RP} / \mathrm{RE} \\
/ \mathrm{MS}\end{array}$ & $\begin{array}{l}\text { S (applicable only to capabilities } \\
\text { which are concerned with account } \\
\text { ownership) }\end{array}$ & $\begin{array}{l}\text { Role } \\
\text { Management } \\
\text { (Identity } \\
\text { Management) }\end{array}$ & N/A & $\begin{array}{l}{[24],} \\
{[4],} \\
{[31],} \\
{[43]}\end{array}$ \\
\hline FC-59 & Fictitious identities & OD/BNA & $\begin{array}{l}\text { S (applicable only to capabilities } \\
\text { which are concerned with account } \\
\text { ownership) }\end{array}$ & $\begin{array}{l}\text { Role } \\
\text { Management } \\
\text { (Identity } \\
\text { Management) }\end{array}$ & N/A & \\
\hline FC-60 & $\begin{array}{l}\text { Decoupling user } \\
\text { credentials \& } \\
\text { physical location }\end{array}$ & BNA & $\begin{array}{l}\text { S (applicable only to capabilities } \\
\text { which are concerned with account } \\
\text { ownership) }\end{array}$ & $\begin{array}{l}\text { Role } \\
\text { Management } \\
\text { (Identity } \\
\text { Management) }\end{array}$ & N/A & [25] \\
\hline
\end{tabular}




\begin{tabular}{|c|c|c|c|c|c|c|}
\hline FC ID & Short Title & $\begin{array}{l}\text { Relevance of } \\
\text { Essential Cloud } \\
\text { Characteristics }\end{array}$ & $\begin{array}{c}\text { Labeling of Challenge/Functional- } \\
\text { Capabilities Correlation }\end{array}$ & $\begin{array}{c}\text { Primary } \\
\text { Category } \\
\text { (Subcategory) }\end{array}$ & $\begin{array}{c}\text { Related } \\
\text { Category } \\
\text { (Subcategory) }\end{array}$ & 苞 \\
\hline FC-61 & $\begin{array}{l}\text { Authentication and } \\
\text { access control }\end{array}$ & RP & $\begin{array}{l}\text { S (applicable only to capabilities } \\
\text { which are concerned with data } \\
\text { classification and access control) }\end{array}$ & $\begin{array}{l}\text { Role } \\
\text { Management } \\
\text { (Identity } \\
\text { Management) }\end{array}$ & N/A & \begin{tabular}{|l}
{$[24]$,} \\
{$[4]$,} \\
{$[29]$,} \\
{$[31]$,} \\
{$[43]$,} \\
{$[48]$}
\end{tabular} \\
\hline FC-62 & $\begin{array}{l}\text { Testability, } \\
\text { validation, and } \\
\text { scientific } \\
\text { principles not } \\
\text { standardized }\end{array}$ & $\begin{array}{l}\mathrm{OD} / \mathrm{BNA} / \mathrm{RP} / \mathrm{RE} \\
/ \mathrm{MS}\end{array}$ & G (applies to most capabilities) & Standards & N/A & \\
\hline FC-63 & $\begin{array}{l}\text { Lack of standard } \\
\text { processes \& } \\
\text { models }\end{array}$ & $\begin{array}{l}\mathrm{OD} / \mathrm{BNA} / \mathrm{RP} / \mathrm{RE} \\
/ \mathrm{MS}\end{array}$ & G (applies to most capabilities) & $\begin{array}{l}\text { Standards } \\
\text { (No Single } \\
\text { Process) }\end{array}$ & N/A & \begin{tabular}{|l}
{$[24]$,} \\
{$[4]$,} \\
{$[36]$,} \\
{$[47]$,} \\
{$[43]$,} \\
{$[61]$}
\end{tabular} \\
\hline
\end{tabular}




\begin{tabular}{|c|c|c|c|c|c|c|}
\hline FC ID & Short Title & $\begin{array}{l}\text { Relevance of } \\
\text { Essential Cloud } \\
\text { Characteristics }\end{array}$ & $\begin{array}{l}\text { Labeling of Challenge/Functional- } \\
\text { Capabilities Correlation }\end{array}$ & $\begin{array}{c}\text { Primary } \\
\text { Category } \\
\text { (Subcategory) }\end{array}$ & $\begin{array}{c}\text { Related } \\
\text { Category } \\
\text { (Subcategory) }\end{array}$ & 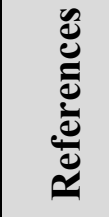 \\
\hline FC-64 & $\begin{array}{l}\text { Limited } \\
\text { knowledge of logs } \\
\text { and records }\end{array}$ & MS & $\begin{array}{l}\text { Q (applies to many capabilities but not } \\
\text { all or most [e.g., not as much } \\
\text { applicability to BOSS]) }\end{array}$ & Training & N/A & [71] \\
\hline FC-65 & $\begin{array}{l}\text { Cloud training for } \\
\text { investigators }\end{array}$ & $\begin{array}{l}\mathrm{OD} / \mathrm{BNA} / \mathrm{RP} / \mathrm{RE} \\
\text { /MS }\end{array}$ & G (applies to most capabilities) & $\begin{array}{l}\text { Training } \\
\text { (Qualification } \\
\text { and } \\
\text { Certification) }\end{array}$ & $\begin{array}{l}\text { Standards } \\
\text { (No Single } \\
\text { Process) }\end{array}$ & $\begin{array}{l}{[24],} \\
{[4],} \\
{[31],} \\
{[32]}\end{array}$ \\
\hline
\end{tabular}


Annex B: CSA's Enterprise Architecture (TCl v2.0)

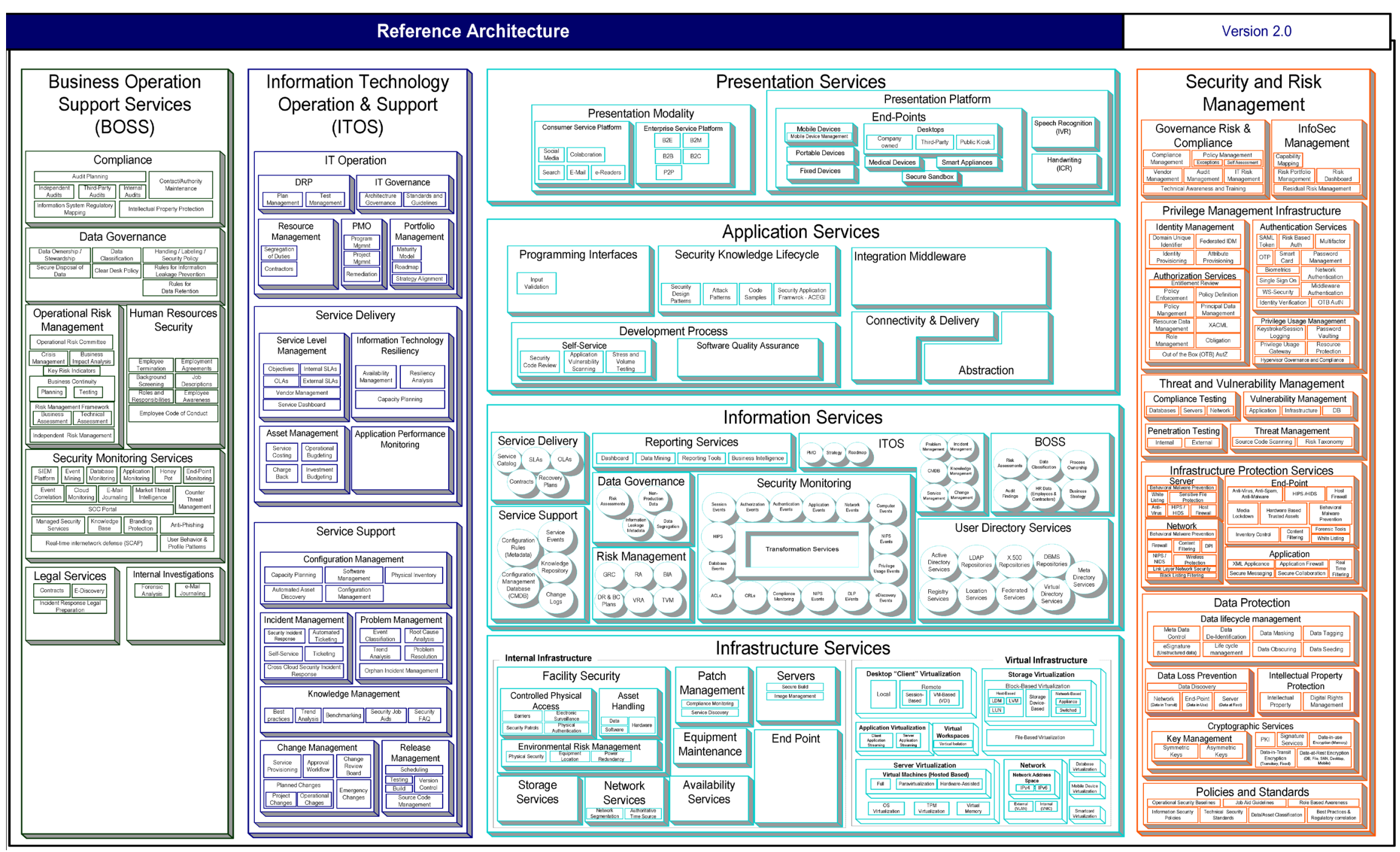


Figure 1: CSA's Enterprise Architecture

Annex C: Mind Maps

Annex C.1: Categories and Subcategories

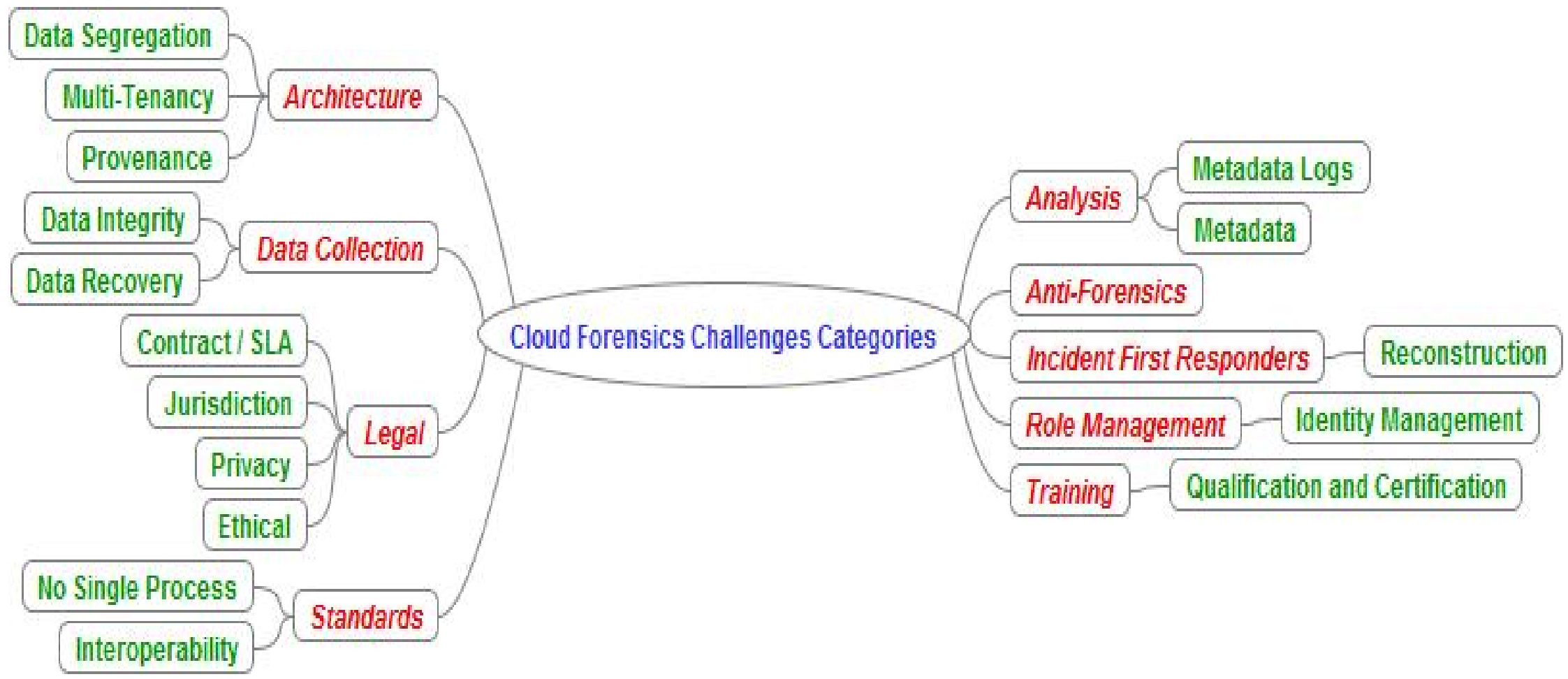

Figure 2: Mind Map - Categories and Subcategories 


\section{Annex C.2: Primary Categories}

Challenge \#21 - Potential evidence segregation Data Segregation

Cortal configurations

Multi-Tenancy

Challenge $\# 22$ - Boundaries

Challenge \#24-Data chain of custody Provenance

Challenge \#01 - Deletion in the cloud

Challenge \#02 - Recovering overwritten data

Challenge \#09 - Interoperability issues among providers

Cinger

Challenge \#13 - Criminals access to low cost computing power

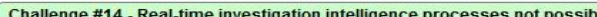

Challenge \#15 - Malicious code may circumvent VM isolation methods

Challenge \#17 - Multiple venues and geolocations

Challenge \#18 - Lack of transparency

Challenge \#19 - Criminals can hide in cloud

Challenge \#29-1maging isolating and collecting dat

Challenge \#41 - Ambiguous trust boundaries

Challenge \#42 - Data integrity and evidence preservation Data Integrity

Challenge \#43 - Root of trust

Challenge \#25 - Decreased access and data control

Challenge \#26 - Chain of depe

Challenge \#27 Locating evidence Challenge \#28 - Data location

Challenge \#29 - Imaging, isolating and collecting data Challenge \#30 - Data available for a limited time

Challenge \#31 - Locating storage media

Challenge \#32 - Evidence identification Challenge \#33 - Dynamic storage

Challenge \# 34 - Live forensics

Challenge \#35 - Resource abstraction

Challenge \#37 - Additional evidence collection

Challenge \#38 - Imaging the cloud

Challenge \#39-Selective data acquisition

Challenge \#40 - Cryptographic key management

Challenge \#45 - Missing terms in contract or SLA Contract/ SLA Challenge \#52 - Lack of international agreements \& laws

Challenge \#53 - Internationar cloud services Challenge \#54 - Jurisdiction

Challenge \#55 - International communication

Challenge $\# 56$ - Confidentiality and PII Privacy

Challenge \#46 - Limited investigative power

Challenge \#47 - Reliance on cloud providers

Challenge \#48 -Physical data location

Challenge \#49 - Port protection Challenge \#51 - E-discovery

Challenge \#63 - Lack of standard processes \& models No Single Process Interoperability

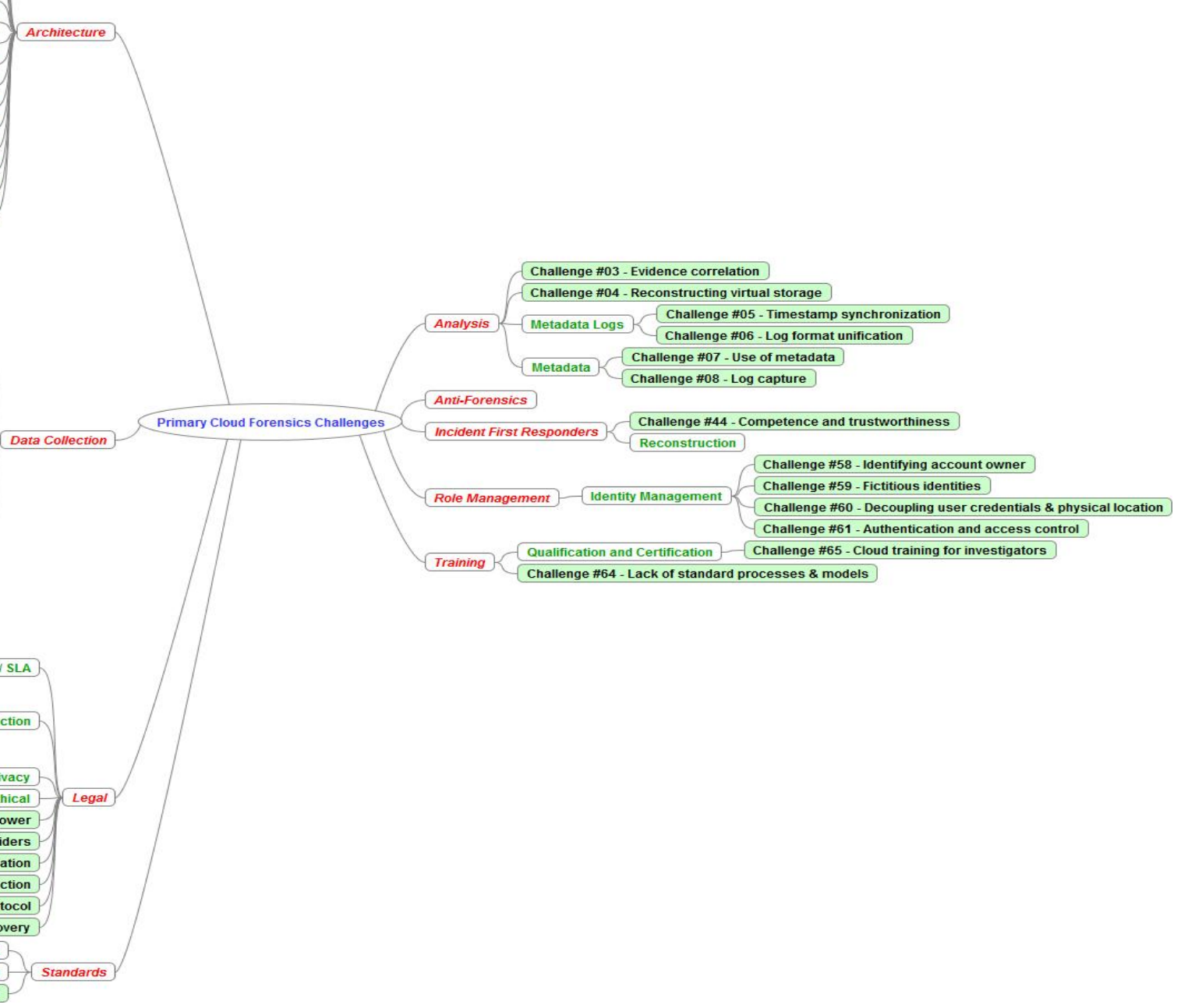

Challenge \#62 - Testability, validation, and scientific principles is not standardized

Figure 3: Mind Map - Primary Categories 


\section{Annex C.3: Related Categories}

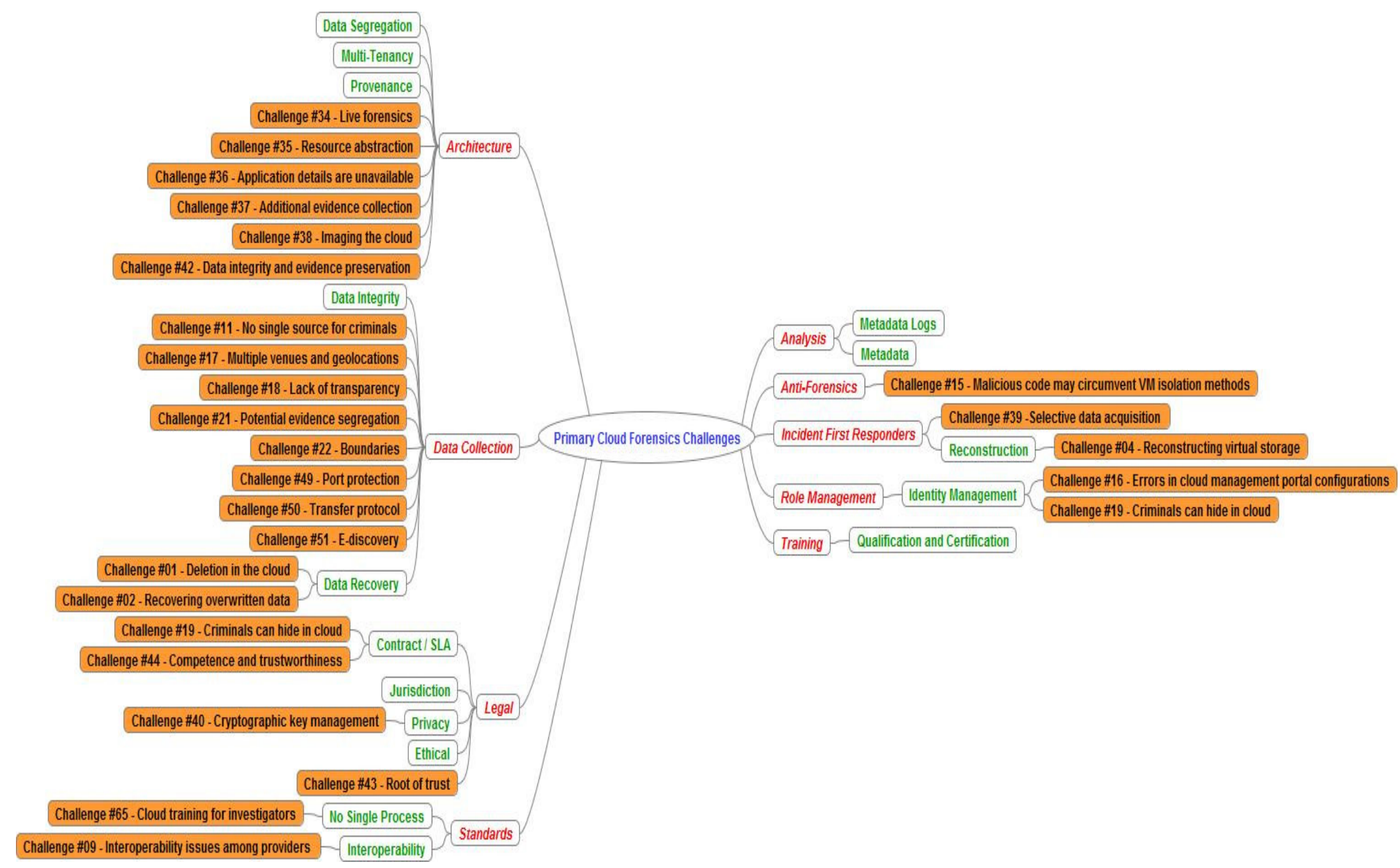

Figure 4: Mind Map - Related Categories 